\title{
Atmospheric water-soluble organic nitrogen (WSON) in the eastern Mediterranean: origin and ramifications regarding marine productivity
}

\author{
Münevver Nehir and Mustafa Koçak \\ Institute of Marine Sciences, Middle East Technical University, P.O. Box 28, 33731, Erdemli-Mersin, Turkey \\ Correspondence: Mustafa Koçak (mkocak@ims.metu.edu.tr)
}

Received: 28 June 2017 - Discussion started: 24 August 2017

Revised: 5 January 2018 - Accepted: 31 January 2018 - Published: 13 March 2018

\begin{abstract}
Aerosol and rain sampling in two size fractions was carried out at a rural site located on the coast of the eastern Mediterranean, Erdemli, Turkey $\left(36^{\circ} 33^{\prime} 54^{\prime \prime} \mathrm{N}\right.$, $34^{\circ} 15^{\prime} 18^{\prime \prime} \mathrm{E}$ ). A total of 674 aerosol samples in two size fractions (337 coarse, 337 fine) and 23 rain samples were collected between March 2014 and April 2015. Samples were analyzed for $\mathrm{NO}_{3}^{-}, \mathrm{NH}_{4}^{+}$and ancillary water-soluble ions using ion chromatography and water-soluble total nitrogen (WSTN) by applying a high-temperature combustion method. The mean aerosol water-soluble organic nitrogen (WSON) was $23.8 \pm 16.3 \mathrm{nmol} \mathrm{N} \mathrm{m}^{-3}$, reaching a maximum of $79 \mathrm{nmol} \mathrm{N} \mathrm{m}^{-3}$, with about $66 \%$ being associated with coarse particles. The volume weighted mean (VWM) concentration of WSON in rain was $21.5 \mu \mathrm{mol} \mathrm{NL} \mathrm{L}^{-1}$. The WSON contributed 37 and $29 \%$ to the WSTN in aerosol and rainwater, respectively. Aerosol WSON concentrations exhibited large temporal variation, mainly due to meteorology and the origin of air mass flow. The highest mean aerosol WSON concentration was observed in the summer and was attributed to the absence of rain and resuspension of cultivated soil in the region. The mean concentration of WSON during dust events $\left(38.2 \pm 17.5 \mathrm{nmol} \mathrm{N} \mathrm{m}^{-3}\right)$ was 1.3 times higher than that of non-dust events $\left(29.4 \pm 13.9 \mathrm{nmol} \mathrm{N} \mathrm{m}^{-3}\right)$. Source apportionment analysis demonstrated that WSON was originated from agricultural activities (43\%), secondary aerosol (20\%), nitrate $(22 \%)$, crustal material $(10 \%)$ and sea salt $(5 \%)$. The dry and wet depositions of WSON were equivalent and amounted to $36 \%$ of the total atmospheric WSTN flux.
\end{abstract}

\section{Introduction}

Research assessing the atmospheric deposition of nitrogen (with a focus on inorganic $\mathrm{N}$ in rainwater i.e., ammonium and nitrate) can be traced back to the mid-1800s (Miller, 1905, and references therein) as it was accepted to be a vital plant nutrient. Miller (1905) mentioned organic nitrogen in rain samples as well. To quote Miller, "With regard to the amount of organic nitrogen in the rainwater, the only available analyses relating to Rothamsted are those of Frankland who found from 0.03 to 0.66 per million in 69 samples". Cornell et al. (1995) highlighted the importance of organic nitrogen in rain and snow accounting for almost half of the total atmospheric dissolved nitrogen deposition. Since then, research defining the quantitative importance of soluble organic nitrogen in the atmospheric transport of nitrogen has greatly expanded (Neff et al., 2002; Cornell et al., 2003; Mace et al., 2003a, b, c; Glibert et al., 2005; Sorooshian et al., 2008; Violaki and Mihalopoulos, 2010; Violaki et al., 2010; Altieri et al., 2016).

Water-soluble organic nitrogen (WSON) arises from a variety of sources including both natural and anthropogenic. Anthropogenic sources include agricultural activities (including fertilizer application, livestock and animal husbandry), cooking, high-temperature fossil fuel combustion, vehicle exhaust, man-made biomass burning and industrial activities. In contrast, natural sources of WSON include mineral dust, bacteria, algal blooms, degraded proteins, sea salt, organic debris and natural biomass burning (Neff et al., 2002; Cornell et al., 2003; Mace et al., 2003a, b, c; Glibert et al., 2005; Sorooshian et al., 2008; Cape et al., 2011; Altieri et al., 2016). Atmospheric organic nitrogen can also be formed 
through chemical reactions. For example, reactions between volatile organic compounds, $\mathrm{NO}_{x}$ and ammonium sulfate aerosols may lead to the formation of nitrogen-containing compounds (Surratt et al., 2008; Galloway et al., 2009; De Haan et al., 2011; Yu et al., 2011). Furthermore, atmospheric organic nitrogen plays an essential role in many global processes which may impact the chemistry of the atmosphere as well as climate and biogeochemical cycles. Similar to ammonium, some organic nitrogen species such as urea and amines have acid-neutralizing capacities (Ge et al., 2011). It has been shown that nitrogen-containing organic compounds nucleate cloud droplets and may contribute considerably to the indirect aerosol effect (Twohy et al., 2005). Phytoplankton and bacteria production in aquatic environments has been found to be stimulated by the addition of water-soluble organic nitrogen (Timperley et al., 1985; Peierls and Paerl, 1997; Seitzinger and Sanders, 1999). The laboratory experiments performed by Seitzinger and Sanders (1999) demonstrated the production of coastal marine bacteria and phytoplankton, which are stimulated by the addition of water-soluble organic nitrogen, $45-75 \%$ being bioavailable. From the mid-1800s to 2000 , as a result of anthropogenic activities, reactive nitrogen and reactive anthropogenic organic nitrogen increased by almost 3- and 5-fold, respectively, leading to a significantly modified global nitrogen cycle (Jickells et al., 2017). This in turn has impacted marine nitrogen biogeochemical cycling (Galloway and Cowling, 2002; Galloway et al., 2008; Duce et al., 2008; Jickells et al., 2017).

The Mediterranean Sea is characterized by oligotrophic surface waters with low-nutrient, low-chlorophyll (LNLC) regions. This has been attributed to mainly anti-estuarine (reverse thermohaline) circulation (Hamad et al., 2005). The eastern Mediterranean (25) has higher molar N / P ratios than those observed in the western Mediterranean (22) and the Redfield ratio (Krom et al., 2004; Y1lmaz and Tuğrul, 1998). Generally, the primary productivity in the eastern Mediterranean is phosphorus-limited (Krom et al., 1991, 2010; Powley et al., 2017). Depending on the season, limitation by nitrogen or co-limitation by nitrogen and phosphorus in the eastern Mediterranean has been reported (Yücel, 2013, 2017, and references therein). Based on molar $\mathrm{N} / \mathrm{P}$ ratios in the atmospheric input (order of magnitude higher than that of Redfield; Markaki et al., 2003, 2010; Koçak et al., 2010) and riverine fluxes (at least 1.8 times larger than that of Redfield; Ludwig et al., 2009; Koçak et al., 2010) it has been suggested that the eastern Mediterranean receives excessive amounts of dissolved inorganic nitrogen and that this unbalanced input may result in even more phosphorus deficiency (Ludwig et al., 2009; Koçak et al., 2010), whilst the atmospheric deposition of reactive nitrogen may cause accumulation of nitrogen in the water column (Jickells et al., 2017). Very little research has focused on the importance of water-soluble organic nitrogen input to marine productivity in the eastern Mediterranean (Mace et al., 2003a; Violaki and Mihalopoulos, 2010; Violaki et al., 2010). Hence, the unique contributions of the current study will be to (i) define the temporal variability of atmospheric water-soluble organic nitrogen, (ii) assign the origin of the water-soluble organic nitrogen, (iii) assess the influence of mineral dust on water-soluble organic nitrogen and (iv) enhance our knowledge of the quantitative dry and wet deposition of water-soluble organic nitrogen and its possible influence on marine productivity in the northeastern Mediterranean.

These aims will be achieved by using the acquired data from the analyses for water-soluble inorganic and organic nitrogen species of a series of size-fractionated aerosol (coarse and fine) and rain samples collected from March 2014 to April 2015 from the northern coast (Erdemli, Turkey) of the Levantine Basin, eastern Mediterranean.

\section{Material and methods}

\subsection{Sampling site description}

Aerosol and rain sampling was carried out at a rural site located on the coast of the eastern Mediterranean, Erdemli, Turkey $\left(36^{\circ} 33^{\prime} 54^{\prime \prime} \mathrm{N}, 34^{\circ} 15^{\prime} 18^{\prime \prime} \mathrm{E}\right)$. The sampling tower (above sea level $\sim 22 \mathrm{~m}, \sim 10 \mathrm{~m}$ away from the sea) is situated at the Institute of Marine Sciences, Middle East Technical University (IMS-METU). Its immediate vicinity is surrounded by cultivated land to the north and to the south of the northern Levantine Basin. Although the site is not under the direct influence of any industrial activities (such as soda production and fertilizer production), the city of Mersin with a population of around 800000 is located $45 \mathrm{~km}$ to the east of the sampling site (Kubilay and Saydam, 1995; Koçak et al., 2012), and hence aerosol and rainwater samples may have been influenced by the aforementioned regional anthropogenic activities when air mass is transported from the east.

\subsection{Sample collection and preparation}

Aerosol. A Gent-type stacked filter unit (SFU) was used to collect aerosol samples in two size fractions (coarse: $d=10$ $2.5 \mu \mathrm{m}$ and fine: $d<2.5 \mu \mathrm{m}$ ) (for more details, see Hopke et al., 1997; Koçak et al., 2007). Briefly, the first section of the filter holder was loaded with an $8 \mu \mathrm{m}$ pore size polycarbonate filter (Whatman Track Etched 111114, circle diameter: $47 \mathrm{~mm}$ ), whilst the second section was loaded with a $0.4 \mu \mathrm{m}$ pore size polycarbonate filter (Whatman Track Etched 111107, circle diameter: $47 \mathrm{~mm}$ ). The cassette unit was then placed into the cylindrical cassette holder, which is designed to prevent the intrusion of particles larger than $10 \mu \mathrm{m}$ when the sampler is operated at a flow rate of 16.0 $16.5 \mathrm{~L} \mathrm{~min}^{-1}$. Daily $(24 \mathrm{~h})$ temporal sample resolution was carried out. Operational blank filters were processed in the same way as the collected samples with the exception that no air was passed through the filters. In order to minimize any possible contamination, the filter loading and unloading were achieved in a laminar airflow cabinet. 
The aerosol sampling campaign commenced in March 2014 and ended in April 2015. During the sampling period, a total of 674 aerosol samples in two size fractions (coarse $=337$; fine $=337$ ) were obtained. The observational coverage of the aerosol sampling period was $80 \%$. The observational coverage for winter, spring, summer and fall was respectively $60,92,81$ and $79 \%$. The seasonal observational coverage, after applying a precision value of 0.3 (for more details, see Sect. 2.4 and Eq. 4), was found to be comparable for winter (49\%), spring (53\%), summer (51\%) and fall (52\%). The sampling was terminated from time to time due to technical malfunction of the SFU and/or the cleaning procedure of the sampling apparatus.

Rain. Rainwater samples were collected using an automatic wet/dry sampler (Model ARS 1000, MTX Italy). A total of 23 rain samples was collected during the sampling period. After each rain event, the rainwater samples were immediately transferred to the laboratory for filtration $(0.4 \mu \mathrm{m}$ Whatman, polycarbonate filters). Operational blanks for rain samples were taken by using $100 \mathrm{~mL}$ of Milli-Q water after cleaning the HDPE buckets with phosphate-free detergent, $\mathrm{HCl}(10 \%)$ and Milli-Q water (3 times).

Storage of samples. Aerosol and rainwater samples were stored frozen $\left(-20^{\circ} \mathrm{C}\right)$ immediately after collection until analyses (not more than a month). Cape et al. (2001) showed that there were no significant losses for inorganic and organic nitrogen during storage (freezing for 3 months) of rain samples with an added biocide.

Sample preparation. In order to determine the concentrations of water-soluble total nitrogen species (WSTN, $\mathrm{NO}_{3}^{-}$ and $\left.\mathrm{NH}_{4}^{+}\right)$and major water-soluble ions $\left(\mathrm{Cl}^{-}, \mathrm{SO}_{4}^{2-}, \mathrm{Na}^{+}\right.$, $\left.\mathrm{K}^{+}, \mathrm{Mg}^{2+}, \mathrm{Ca}^{2+}\right)$ in an aerosol sample, one-quarter of the filter was extracted for $60 \mathrm{~min}$ in $20 \mathrm{~mL}$ ultra-pure water $(18.2 \Omega \mathrm{m})$ by mechanic shaking. About $100 \mu \mathrm{L}$ chloroform (Merc 2444, 99.8\%) was added as a preservative to prevent biological activity after removing the filter (Bardouki et al., 2003; Koçak et al., 2007). Before measuring the watersoluble species, extracts were filtered with $0.4 \mu \mathrm{m}$ pore size polycarbonate filters.

\subsection{Chemical analysis}

Water-soluble total nitrogen. High-temperature catalytic oxidation (Torch Teledyne Tekmar TOC/TN) was applied to determine the WSTN concentrations in the aerosol and rainwater samples. The liquid aliquot of the sample is injected into the combustion furnace $\left(750^{\circ} \mathrm{C}\right)$ and the $\mathrm{N}$ in the sample was then converted to NO gas. The carrier gas (high-purity dry air) sweeps the sample into the nondispersive infrared detector. From here, the sample is carried to the nitrogen module. In this unit $\mathrm{NO}$ is mixed with $\mathrm{O}_{3}$ since the chemiluminescent detection of NO is based on the reaction between $\mathrm{NO}$ and $\mathrm{O}_{3}$. After the formation of excited nitrogen dioxide $\left(\mathrm{NO}_{2}^{*}\right)$, the extra energy is given off as light when $\mathrm{NO}_{2}^{*}$ relaxes to its ground state. The light signal to an electronic signal for quan- tification is then measured by a chemiluminescence detector with a photomultiplier tube.

The standards were prepared from $\mathrm{KNO}_{3}$ of high purity (>99\%, Merck Extra Pure, CC551961). In order to evaluate accuracy of the WSTN measurements, nitrate, ammonium, urea and mixture of these species were detected by a Teledyne Tekmar torch instrument. Recovery for these substances was better than $92 \%$. In addition, the accuracy of the total nitrogen determination by the instrument was verified against intercalibration samples of the QUASIMEME program (Quality Assurance of Information for Marine Environmental Monitoring in Europe). Correspondingly, recoveries for QNU277SW (IMS-METU $=4.67 \mu \mathrm{M}$, Mean $=5.17 \mu \mathrm{M}$ ), QNU278SW (IMS-METU $=10.41 \mu \mathrm{M}$, Mean $=11.30 \mu \mathrm{M})$ and QNU279SW (IMS-METU $=4.67 \mu \mathrm{M}$, Mean $=5.17 \mu \mathrm{M}$ ) were 90,92 and $83 \%$. Blank values of WSTN for aerosol and rain samples were less than the limit of detection $(3.6 \mathrm{nmol})$.

Water-soluble inorganic and ancillary species. In addition to $\mathrm{NO}_{3}^{-}$and $\mathrm{NH}_{4}^{+}$, major water-soluble ions concentrations were measured by using a Dionex ICS-5000 ion chromatography instrument. Water-soluble anions $\left(\mathrm{Cl}^{-}, \mathrm{SO}_{4}^{2-}\right.$, $\mathrm{NO}_{3}^{-}$) were determined by applying a AS11-HC separation column, KOH (30 mM) eluent and AERS-500 (4 mm) suppressor whilst water-soluble cations $\left(\mathrm{Na}^{+}, \mathrm{K}^{+}, \mathrm{Mg}^{2+}, \mathrm{Ca}^{2+}\right)$ were detected electrochemically by using a CS12-A separation column, MSA (20 mM) eluent and CSRS-300 (4 mm) suppressor (Product Manual for Dionex IonPac AS11-HC$4 \mathrm{~m}$, IonPac CS12A Manual). The blank contributions for all water-soluble ions in aerosol samples were found to be less than $10 \%$ and concentrations were corrected for blanks.

\subsection{Calculations}

WSON concentrations (see Eq. 1) were determined from the difference between the individual concentrations of WSTN and water-soluble inorganic nitrogen (WSIN) (see Eq. 2) since there is no direct analytical method to detect the concentration of water-soluble organic nitrogen. The precision for WSON was calculated via the formula (see Eq. 3) suggested by Hansell (1993). The precision $\left(75 \mathrm{nmol} \mathrm{N} \mathrm{m}^{-3}\right.$ ) was found to be almost 3 times higher (see Eq. $4, R \sim 0.3$ ) than that of the arithmetic mean of WSON in aerosols, whilst it $\left(90 \mu \mathrm{mol} \mathrm{N} \mathrm{L}{ }^{-1}\right)$ was estimated to be approximately 4 times larger than that of the volume weighted mean of WSON in rain. Such high values are not unusual. For example, if the data presented by Mace et al. (2003a) had been used, precisions would have been 5 and 8 times higher than those of the concentrations of WSON in aerosol and rain, respectively. Table 1 shows the number of negative WSON values and the positive WSON biases for coarse and fine modes. Correspondingly, about $5(n=18)$ and $15 \%(n=52)$ of the values were negative in coarse and fine particles. The substitution with zero yielded 2 and $14 \%$ positive bias for the coarse and fine mode; whereas the omission of zero resulted in 8 and $34 \%$ positive bias in coarse and fine WSON 
Table 1. The number of negative WSON values and positive biases in coarse and fine particles at Erdemli.

\begin{tabular}{|c|c|c|}
\hline & Coarse & Fine \\
\hline Number of samples & 337 & 337 \\
\hline Number of negatives & 18 & 52 \\
\hline $\mathrm{SZ}^{1}$-positive bias (\%) & 2 & 14 \\
\hline $\mathrm{PZ}^{2}$-positive bias (\%) & 8 & 34 \\
\hline
\end{tabular}

1 and 2 refer to as the substitution with zero and the omission of zero for arithmetic mean, respectively.

mean concentrations. Consequently, the presentation of the general characteristics of the data includes all negative concentrations (see Table 1) and the values presented in Table 1 will be used for calculating dry and wet deposition. It has been stated that the uncertainty in WSON concentrations results from the additions of errors such as the oxidation efficiency of the method, the sampling material, the storage of the samples and the usage of preservatives (Cape et al., 2011). These authors have particularly pointed out the low precision for samples with low concentrations of WSON and high levels of WSIN (see Eq. 2). Although the calculation of precision for WSON is very difficult owing to the aforementioned errors, Hansell (1993) has proposed the estimation of precision for WSON exclusively relying on measured WSTN and WSIN concentrations. Consequently, in order to evaluate the variability in the aerosol WSON and apply positive matrix factorization (PMF), however, a different approach was adopted. To this end, arbitrary thresholds have been defined as the ratio between the WSON mean concentration and the calculated precision (see Eq. 4). Thus, during assessment of the variability in aerosol WSON and the application of PMF, WSON concentrations with $R$ values larger than 0.3 will be considered since the arbitrary threshold simply reduces the uncertainty. A total of 216 aerosol samples was found to have higher $R$ values than 0.3 .

$$
\begin{aligned}
& \mathrm{WSON}=\mathrm{WSTN}-\mathrm{WSIN} \\
& \mathrm{WSIN}=\mathrm{NO}_{3}^{-}+\mathrm{NH}_{4}^{+} \\
& S_{\mathrm{WSON}}=\left(s_{\mathrm{WSTN}}^{2}+s_{\mathrm{WSIN}}^{2}\right)^{1 / 2} \\
& R=\frac{\mathrm{WSON}_{\mathrm{MEAN}}}{S_{\mathrm{WSON}}}
\end{aligned}
$$

The rain volume weighted average concentration $\left(C_{\mathrm{W}}\right)$ of nitrogen species can be calculated as follows:

$$
C_{\mathrm{W}}=\frac{\sum_{i=1}^{n} C_{i} x Q_{i}}{\sum_{i=1}^{n} Q_{i}} .
$$

The wet and dry atmospheric fluxes of nitrogen species were calculated according to the procedure explained in Herut et al. $(1999,2002)$. The wet atmospheric deposition fluxes $\left(F_{\mathrm{w}}\right)$ were calculated from the annual precipitation $\left(P_{\text {annual }}\right)$ and the volume weighted mean concentration $\left(C_{\mathrm{W}}\right)$ of the substance of interest.

$F_{\mathrm{W}}=C_{\mathrm{W}} \times P_{\text {annual }}$

The dry deposition $\left(F_{\mathrm{d}}\right)$ is calculated as the product of the atmospheric mean nutrient concentrations $\left(C_{\mathrm{d}}\right)$ and their settling velocities $\left(V_{\mathrm{d}}\right)$, where $F_{\mathrm{d}}$ is given in units of $\mu \mathrm{mol} \mathrm{m}{ }^{-2} \mathrm{yr}^{-1}, C_{\mathrm{d}}$ in units of $\mu \mathrm{mol} \mathrm{m}{ }^{-3}$ and $V_{\mathrm{d}}$ in units of $\mathrm{m} \mathrm{yr}^{-1}$.

$F_{\mathrm{d}}=C_{\mathrm{d}} \times V_{\mathrm{d}}$

The settling velocities $\left(V_{\mathrm{d}}\right.$; see Eq. 8) for each watersoluble nitrogen species were calculated by using an approach adopted by Spokes et al. (2001). $C_{\mathrm{c}}$ and $C_{\mathrm{f}}$ refer to the relative contribution of coarse and fine modes, and 2.0 and $0.1 \mathrm{~cm} \mathrm{~s}^{-1}$ are deposition velocities proposed by Duce et al. (1991) for coarse and fine particles, respectively.

$V_{\mathrm{d}}=C_{\mathrm{c}} \times 2.0+C_{\mathrm{f}} \times 0.1$

\subsection{Air mass back trajectories and airflow classification}

Three-day back trajectories of air masses at the four altitude levels (1000, 2000, 3000 and $4000 \mathrm{~m}$ ) arriving at Erdemli station were computed by using the HYSPLIT dispersion model (HYbrid Single-Particle Lagrangian Integrated Trajectory; Draxler and Rolph, 2003). Three-day back trajectories reaching the altitude of $1000 \mathrm{~m}$ were classified into six sectors: (i) Middle East, (ii) north Africa, (iii) Turkey, (iv) eastern Europe, (v) western Europe and (vi) the Mediterranean Sea, in order to assess the influence of airflow on WSON concentration in $\mathrm{PM}_{10}$ (for more details, see Koçak et al., 2012).

\subsection{Positive matrix factorization (PMF) for source apportionment of WSON}

The receptor modeling tool positive matrix factorization (US Environmental Protection Agency PMF version 5.0, hereinafter referred to as "PMF") was utilized to identify the sources of WSON in $\mathrm{PM}_{10}$ at Erdemli. PMF has been proven to be a robust tool in characterizing the sources of aerosol (Paatero and Tapper, 1994; Huang et al., 1999; Lee et al., 1999; Viana et al., 2008; Koçak et al., 2009; for more details, see Appendix A). EPA PMF 5.0 software mainly consists of model run and rotational tools (see EPA/600/R-14/108; US EPA, 2014). Before application of the software, the user must supply two input files, namely concentration and uncertainty. The former contains concentrations of the aerosol species whilst the latter contains the corresponding uncertainty for each variable. Uncertainty was set to $5 \%$ for each species with the exception of WSON (15\%) since WSON exclusively exhibited high uncertainty (for more details, see 
Appendix A). The base run of PMF was achieved by setting the number of runs and random starting points (in other words, seeds) to 250 and 50, respectively. Base model displacement (DISP), bootstrap (BS) and bootstrap displacement (BS-DISP) methods were sequentially used after the base run. The DISP accesses the rotational ambiguity. DISP error estimates showed that there were no factor swaps and significant decrease in $Q$ during DISP, being 0 and 0.00 , respectively. Therefore, DISP results did not reveal rotational ambiguity, implying the solutions to be robust. Except in one case, results from BS and BS-DISP $(n=50)$ did not indicate any asymmetry or rotational ambiguity for five factors. To evaluate the rotational ambiguity, different Fpeak values were applied, considering changes in $\mathrm{d} Q$ to be less than $5 \%$. Furthermore, G-shape plots of Fpeak solutions were examined to determine convergence toward the axis or lower/zero contribution. Thus, an Fpeak value of -0.7 was used and five factors were identified by using PMF 5.0. BS of Fpeak at -0.7 did not reveal any swaps for five factors. The slope of the estimated WSON against measured WSON was $10 \%$ less than unity with a correlation coefficient and intercept of 0.87 and $1.5\left(\mathrm{nmol} \mathrm{N} \mathrm{m}^{-3}\right)$, respectively.

\section{Results and discussion}

\subsection{General characteristics of the data}

In this section the general characteristics of the watersoluble organic nitrogen (WSON), nitrate $\left(\mathrm{NO}_{3}^{-}\right)$, ammonium $\left(\mathrm{NH}_{4}^{+}\right)$and water-soluble total nitrogen (WSTN) in aerosol and rain will be discussed.

Aerosol. The statistical summary for WSON, $\mathrm{NO}_{3}^{-}, \mathrm{NH}_{4}^{+}$ and WSTN in $\mathrm{PM}_{10}$ aerosol samples obtained from Erdemli between March 2014 and April 2015 is presented in Table 2. Median values for WSON, $\mathrm{NO}_{3}^{-}, \mathrm{NH}_{4}^{+}$and WSTN were, respectively, 10, 20, 40 and $10 \%$ lower than those of arithmetic means. Among the nitrogen species, WSON exhibited the highest arithmetic mean, followed by ammonium and nitrate concentrations. The maximum concentration of WSON was estimated to be $79 \mathrm{nmol} \mathrm{N} \mathrm{m}^{-3}$, with a mean value and standard deviation of $23.8 \pm 16.3 \mathrm{nmol} \mathrm{N} \mathrm{m}^{-3}$. The observed arithmetic was comparable to that reported by Mace et al. (2003a) for the same site. Approximately $66 \%$ of the WSON was associated with coarse particles; the remaining fraction (34\%) was present within the fine mode. A number of studies have reported the relative size distribution of WSON for the eastern Mediterranean marine aerosol (Finokalia; Violaki and Mihalopoulos, 2010) and aerosol observed at remote marine sites (Hawaii; Cornell et al., 2001; Tasmania, Mace et al., 2003b). The aerosol WSON at Finokalia $(68 \%)$ and Hawaii was primarily found in the fine mode, whilst WSON in South Pacific marine aerosol (Tasmania) was mainly associated with the coarse fraction. It is likely that the WSON at Erdemli (a) is relatively less im-
Table 2. The statistical summary of the WSON, $\mathrm{NO}_{3}^{-}, \mathrm{NH}_{4}^{+}$and WSTN for aerosol $\left(\mathrm{nmol} \mathrm{N} \mathrm{m}{ }^{-3}\right)$ and rain $\left(\mu \mathrm{mol} \mathrm{NL^{-1 }}\right)$ samples collected at Erdemli from March 2014 to April 2015.

\begin{tabular}{|c|c|c|c|c|}
\hline \multicolumn{5}{|c|}{ Aerosol (nmol N m${ }^{-3}$ ) number of samples: 337} \\
\hline & WSTN & WSON & $\mathrm{NO}_{3}^{-}$ & $\mathrm{NH}_{4}^{+}$ \\
\hline Arithmetic mean & 63.5 & 23.8 & 17.8 & 21.9 \\
\hline Standard deviation & 32.0 & 16.3 & 15.2 & 23.8 \\
\hline Median & 57.7 & 21.4 & 14.3 & 14.3 \\
\hline Minimum & 9.7 & -27.9 & 0.2 & 0.5 \\
\hline Maximum & 176.5 & 79.0 & 88.4 & 164.4 \\
\hline Coarse / $\mathrm{PM}_{10}(\%)$ & 51 & 66 & 87 & 4 \\
\hline $\begin{array}{l}\text { Relative contribution } \\
\text { to WSTN }(\%)\end{array}$ & & 37 & 28 & 35 \\
\hline \multicolumn{5}{|c|}{ Rain $\left(\mu \mathrm{mol} \mathrm{N} \mathrm{m}{ }^{-3}\right)$ number of samples: 23} \\
\hline VWM* & 73.5 & 21.5 & 23.3 & 28.7 \\
\hline Minimum & 24.3 & -2.9 & 0.2 & 9.1 \\
\hline Maximum & 356.2 & 257.2 & 74.6 & 122.6 \\
\hline $\begin{array}{l}\text { Relative contribution } \\
\text { to WSTN }(\%)\end{array}$ & & 29 & 32 & 39 \\
\hline
\end{tabular}

* VWM refers to volume weighted mean.

pacted by anthropogenic sources and/or (b) is more influenced by mineral dust transport and resuspension of cultivated soil compared to that observed at Finokalia.

$\mathrm{NO}_{3}^{-}$and $\mathrm{NH}_{4}^{+}$aerosol concentrations ranged between $0.2-88.4$ and $0.5-164.4 \mathrm{nmol} \mathrm{N} \mathrm{m}^{-3}$, with mean values (standard deviations) of $17.9( \pm 15.7)$ and 23.3 $( \pm 24.4) \mathrm{nmol} \mathrm{N} \mathrm{m}^{-3}$. As expected, $\mathrm{NO}_{3}^{-}$was mainly associated with coarse particles, accounting for $87 \%$ of the observed mean value, while $\mathrm{NH}_{4}^{+}$was dominant in the fine mode, contributing $96 \%$ to the detected mean concentration. Similar results have been reported for eastern Mediterranean marine aerosol (Bardouki et al., 2003; Koçak et al., 2007). The predominance of $\mathrm{NO}_{3}^{-}$in the coarse mode might be due to gaseous nitric acid or other nitrogen oxides reacting with alkaline sea salts and mineral dust particles. In contrast, the occurrence of $\mathrm{NH}_{4}^{+}$in the fine fraction is mainly as a result of the reaction between gaseous alkaline ammonia and acidic sulfuric acid (Mihalopoulos et al., 2007).

WSTN concentrations in aerosols varied between 9.7 and $176.5 \mathrm{nmol} \mathrm{N} \mathrm{m}^{-3}$ with an arithmetic mean value of $63.5 \pm 32.0 \mathrm{nmol} \mathrm{N} \mathrm{m}^{-3}$. The mean WSTN concentration was almost equally influenced by coarse $(51 \%)$ and fine particles $(49 \%)$. Table 2 demonstrates the relative contributions of WSON, $\mathrm{NO}_{3}^{-}$and $\mathrm{NH}_{4}^{+}$to the WSTN in $\mathrm{PM}_{10}$. As can be deduced from the table, the WSTN concentration was equally influenced by WSON and $\mathrm{NH}_{4}^{+}$, each species contributing 37 and $35 \%$, respectively. In contrast the contribution of $\mathrm{NO}_{3}^{-}$to WSTN was found to be $28 \%$. 
Rain. Volume weighted mean (VWM) concentrations of WSON, $\mathrm{NO}_{3}^{-}, \mathrm{NH}_{4}^{+}$and WSTN in rainwater are presented in Table 2, along with the minimum and maximum concentrations as well as the relative contributions of WSON, $\mathrm{NO}_{3}^{-}$and $\mathrm{NH}_{4}^{+}$to WSTN. As can be deduced from the table, VWM concentrations of each species were comparable and $\mathrm{NH}_{4}^{+}$exhibited the highest concentration, with a value of $28.7 \mu \mathrm{mol} \mathrm{N} \mathrm{L}{ }^{-1}$. The VWM concentrations of WSON and $\mathrm{NO}_{3}^{-}$were 21.5 and $23.3 \mu \mathrm{mol} \mathrm{NL}{ }^{-1}$, respectively. Considering their relative contributions to WSTN, WSON and $\mathrm{NO}_{3}^{-}$ account for 29 and $32 \%$ of the WSTN, whilst $\mathrm{NH}_{4}^{+}$represented $39 \%$ of the observed WSTN concentration in rainwater.

\subsection{Comparison of WSON in aerosol and rain with data from the literature}

The concentrations of WSON in marine aerosols and rain samples collected from different sites located around the Mediterranean, Atlantic and Pacific regions are illustrated in Table 3. Comparing the current WSON values with those reported in the literature is challenging due to (i) different applied sampling periods, sampling and measurement techniques and (ii) the high uncertainty associated with the estimation of WSON. Furthermore, within the literature there is a lack of information defining the uncertainty of WSON though there is a substantial statistical knowledge. Keene at al. (2002), in particular, have highlighted the tendency in the literature to neglect negative values or substitute such values with zero instead when calculating the WSON from the difference between WSTN and WSIN. As these authors have highlighted, the omission or substitution of such values inevitably would result in a positive bias in the WSON concentrations.

In general, the lowest concentrations in aerosols were found in those derived from remote or pristine marine environments. The WSON concentrations in the atmosphere over the Indian (Amsterdam Island: $1.0 \mathrm{nmol} \mathrm{N} \mathrm{m}^{-3}$, Violaki et al., 2015), Atlantic (Barbados: $1.3 \mathrm{nmol} \mathrm{N} \mathrm{m}^{-3}$, Zamora et al., 2011) and Pacific Ocean (Hawaii, Oahu: $4.1 \mathrm{nmol} \mathrm{N} \mathrm{m}^{-3}$, Cornell et al., 2001, Tasmania: $5.3 \mathrm{nmol} \mathrm{N} \mathrm{m}^{-3}$, Mace et al., 2003b) were at least 4 times less than those observed for the eastern Mediterranean (Erdemli: $23.8 \mathrm{nmol} \mathrm{N} \mathrm{m}^{-3}$, this study; Finokalia: $17.1 \mathrm{nmol} \mathrm{N} \mathrm{m}^{-3}$, Violaki and Mihalopoulos, 2010). These lower values might be attributed to (i) the absence of the strong anthropogenic sources in the vicinity of the sampling sites, (ii) the dilution of the WSON originating from long-range transport via both dry and wet deposition and/or (iii) small contributions from non-landbased local emissions such as sea salt and algal blooms. The highest WSON concentrations emerged particularly over China (Ho et al., 2015, concentration of WSON measured in $\mathrm{PM}_{2.5}$ ) and Taiwan (Chen et al., 2010), with values above $70 \mathrm{nmol} \mathrm{N} \mathrm{m}^{-3}$. As stated in Chen et al. (2010) WSON concentrations at these sampling sites were markedly influ-

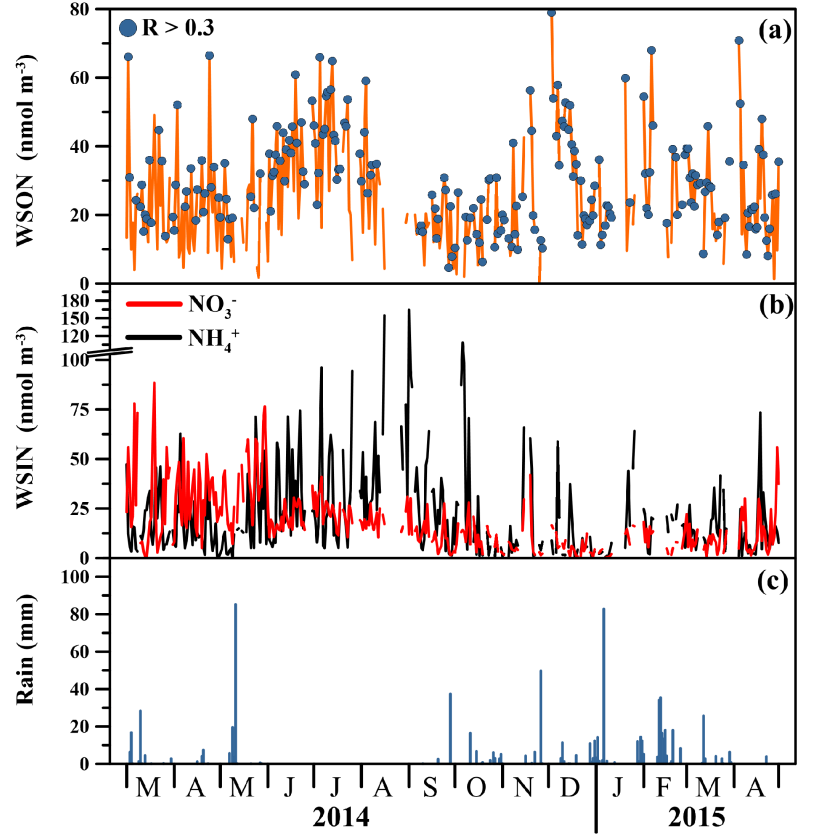

Figure 1. The daily variation in the concentrations of (a) WSON, (b) $\mathrm{NO}_{3}^{-}$and (c) $\mathrm{NH}_{4}^{+}\left(\mathrm{nmol} \mathrm{N} \mathrm{m}^{-3}\right)$ together with rain amount (mm) from March 2014 to April 2015 for $\mathrm{PM}_{10}$.

enced by anthropogenic activities such as fossil fuel combustion and human-induced biomass burning. Concentrations over the Amazon (Mace et al., 2003c) in the dry season $\left(61 \mathrm{nmol} \mathrm{N} \mathrm{m}^{-3}\right)$ have also been noted. Such high values were ascribed to natural fires (Mace et al., 2003c). The mean WSON concentration at Erdemli $\left(23.8 \mathrm{nmol} \mathrm{N} \mathrm{m}^{-3}\right)$ was comparable to that reported previously for the same site (29 nmol $~ m^{-3}$, Mace et al., 2003a). In contrast, the present WSON concentration was almost 1.5 times higher than that observed at Finokalia (Violaki and Mihalopoulos, 2010).

The reported WSON values for rain also exhibited the lowest concentrations in those derived from remote or pristine marine environments, such as Hawaii $\left(2.8 \mu \mathrm{mol} \mathrm{N} \mathrm{L}{ }^{-1}\right.$, Cornell et al., 2001). The highest WSON concentrations were observed in China (North China Plain: $103 \mu \mathrm{mol} \mathrm{N} \mathrm{L}^{-1}$, Zhang et al., 2008) and in Norwich, UK $\left(33 \mu \mathrm{mol} \mathrm{NL}{ }^{-1}\right.$, Cornell et al., 1998). These high values were again attributed to the anthropogenic sources.

\subsection{Temporal variability of water-soluble nitrogen species in aerosol Erdemli}

Figure 1 illustrates daily variation of the water-soluble nitrogen species in aerosol samples together with the daily rainfall from March 2014 to April 2015. The same figure also presents the concentrations in rainwater samples collected between October 2014 and April 2015. It is clear that WSON concentrations exhibited large variation from one day to another day. The daily variability in the concentra- 
Table 3. Comparison of WSON concentrations in aerosol $\left(\mathrm{nmol} \mathrm{N} \mathrm{m}^{-3}\right)$ and rain $\left(\mu \mathrm{mol} \mathrm{N} \mathrm{L}^{-1}\right)$ samples for different sites of the world.

\begin{tabular}{|c|c|c|c|c|}
\hline Aerosol $\left(\mathrm{nmol} \mathrm{N} \mathrm{m}^{-3}\right)$ & WSON & NS & SP & Reference \\
\hline \multicolumn{5}{|l|}{ Mediterranean Sea } \\
\hline Erdemli, Turkey & 23.8 & 674 & 2014-2015 & This study \\
\hline Erdemli, Turkey & 29 & 39 & 2000 & Mace et al. (2003a) \\
\hline Finokalia, Crete & 17.1 & 65 & 2005-2006 & Violaki and Mihalopoulos (2010) \\
\hline \multicolumn{5}{|l|}{ Pacific Ocean } \\
\hline Hawaii & 4.1 & 16 & 1998 & Cornell et al. (2001) \\
\hline Tasmania & 5.3 & 24 & 2000 & Mace et al. (2003b) \\
\hline Taiwan & 75.9 & 77 & 2006 & Chen et al. (2010) \\
\hline Xi'an, China $\left(\mathrm{PM}_{2.5}\right)$ & 300 & 65 & 2008-2009 & Ho et al. (2015) \\
\hline \multicolumn{5}{|l|}{ Atlantic Ocean } \\
\hline Barbados & 1.3 & 57 & 2007-2008 & Zamora et al. (2011) \\
\hline Amazon, dry season & 61 & 37 & 1999 & Mace et al. (2003c) \\
\hline Amazon, wet season & 3.5 & 27 & 1999 & Mace et al. (2003c) \\
\hline \multicolumn{5}{|l|}{ Indian Ocean } \\
\hline Amsterdam Island & 1 & 42 & 2005 & Violaki et al. (2015) \\
\hline Rainwater $\left(\mu \mathrm{mol} \mathrm{N} \mathrm{L}{ }^{-1}\right)$ & WSON & NS & SP & Reference \\
\hline \multicolumn{5}{|l|}{ Mediterranean Sea } \\
\hline Erdemli, Turkey & 21.5 & 23 & 2014-2015 & This study \\
\hline Erdemli, Turkey & 15 & 18 & 2000 & Mace et al. (2003a) \\
\hline Finokalia, Crete & 18 & 18 & 2003-2006 & Violaki et al. (2010) \\
\hline \multicolumn{5}{|l|}{ Pacific Ocean } \\
\hline Tahiti* $^{*}$ & 4.8 & 8 & & Cornell et al. (1998) \\
\hline Hawaii & 2.8 & 17 & 1998 & Cornell et al. (2001) \\
\hline Tasmania & 7.2 & 6 & & Mace et al. (2003b) \\
\hline North China Plain, China & 103 & 15 & 2003-2005 & Zhang et al. (2008) \\
\hline Kilauea, Hawaii & 6.5 & 20 & 1998 & Cornell et al. (2001) \\
\hline \multicolumn{5}{|l|}{ Atlantic Ocean } \\
\hline Bermuda & 5.6 & 5 & 1994 & Cornell et al. (1998) \\
\hline Mace Head & 3.3 & 7 & & Cornell et al. (1998) \\
\hline Norwich, UK & 33 & 12 & & Cornell et al. (1998) \\
\hline Virginia, United States & 3.1 & 83 & 1996-1999 & Keene et al. (2002) \\
\hline Delaware, United States & 4.2 & 50 & 1997-1999 & Keene et al. (2002) \\
\hline New Hampshire, United States & 0.6 & 12 & 1997 & Keene et al. (2002) \\
\hline
\end{tabular}

* RC, NS and SP refer to relative contribution of WSON to WSTN, number of samples and sampling period, respectively.

tion of WSON may be an order of magnitude. Such variability has also been reported in Atlantic (Zamora et al., 2011), Pacific (Chen et al., 2010) and eastern Mediterranean marine aerosols (Violaki and Mihalopoulos, 2010). These studies demonstrated that the daily change in the concentrations of WSON arises from a combination of (a) meteorological parameters (such as rain, temperature and wind speed/direction), (b) chemical reactions, (c) history of air masses back trajectories and (d) source emission strength.
In general, lower concentrations of WSON were found to be associated with rainy days. To serve as an illustration, one of the lowest WSON concentrations was observed on 19 October 2014, after two consecutive days of rainfall, with a value of $6 \mathrm{nmol} \mathrm{N} \mathrm{m}^{-3}$. In contrast, one of the highest observed WSON concentrations $\left(66.1 \mathrm{nmol} \mathrm{N} \mathrm{m}^{-3}\right)$ was detected on 2 March 2014, when the air mass back trajectories were associated with south/southwesterly airflow (for more details, see Sect. 3.4). Another high concentration of WSON was observed on 5 July 2014, with 


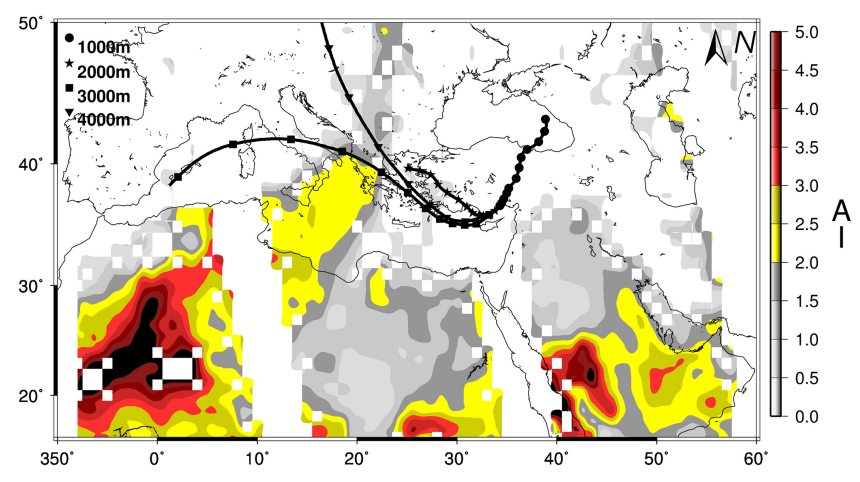

Figure 2. Three-day back trajectories showing the transport of air masses $1000 \mathrm{~m}$ (black circle), $2000 \mathrm{~m}$ (black star), $3000 \mathrm{~m}$ (black square) and $4000 \mathrm{~m}$ (black triangle) on 5 July 2014 for Erdemli. Aerosol index (AI) from OMI (Ozone Mapping Instrument) distribution also illustrated with a color bar from grey to dark red.

a value of $66 \mathrm{nmol} \mathrm{N} \mathrm{m}^{-3}$. A total of $94 \%$ of the WSON was present in the coarse mode; however, during this event there was no intense dust intrusion either from the Sahara or from the Middle Eastern deserts. The corresponding OMI$\mathrm{AI}$ and $\mathrm{nssCa}^{2+}\left(33 \mathrm{nmol} \mathrm{m}^{-3}\right)$ also support this observation (see Fig. 2). Lower layer air mass back trajectories (1000 and $2000 \mathrm{~m}$ ) demonstrated that Erdemli was under the influence of north/northwesterly airflow from Turkey after passing over Turkey's largest cultivated plain, Konya. Thus, this high value might be attributed to resuspension of the soil affected by intense agricultural activities. On 20 January 2015 the WSON concentration was $60 \mathrm{nmol} \mathrm{N} \mathrm{m}^{-3}, 72 \%$ being present in the fine mode. For this event, the $\mathrm{NH}_{4}^{+}$concentration was $20 \mathrm{nmol} \mathrm{N} \mathrm{m}^{-3}, 2$ times higher than the observed arithmetic mean in winter. Corresponding trajectories, AOD (aerosol optical depth) and AC (Ångström component) images are presented in Fig. 3. Airflow at $1 \mathrm{~km}$ showed air mass flow arriving at the sampling site from Turkey. AOD values over the sampling site and coastline of northeastern Mediterranean ranged from 0.2 to 0.5 , whilst $\mathrm{AC}$ values demonstrated that the region was dominated by fine particles. Based on the above indicators, it may be concluded that anthropogenic sources were dominant.

A summary of the statistical analyses of the seasonal dataset of aerosol-associated WSON, $\mathrm{NO}_{3}^{-}$and $\mathrm{NH}_{4}^{+}$is shown in Table 4. The Mann-Whitney U test indicated that there was a statistically significant difference among seasons, such that summer $>$ spring $\approx$ winter $>$ fall. The arithmetic mean value of WSON in the summer was found to be 1.3 and 2.0 times greater than that observed for spring/winter and fall, respectively. Percent WSON contributions of coarse mode for winter $(50 \%)$, spring $(50 \%)$ and fall $(55 \%)$ were comparable. However, WSON was chiefly associated with coarse particles in summer, amounting to $83 \%$. This high value in summer might be due to the absence of rainfall (see Fig. 1) and enhanced resuspension of cultivated soil in the
Table 4. Seasonal statistical summary of the WSON, $\mathrm{NO}_{3}^{-}, \mathrm{NH}_{4}^{+}$, WSTN $\left(\mathrm{nmol} \mathrm{N} \mathrm{m}^{-3}\right)$ and $\mathrm{nssCa}^{2+}\left(\mathrm{nmol} \mathrm{m}^{-3}\right)$ in aerosol samples collected at Erdemli from March 2014 to April 2015.

\begin{tabular}{lrrrr}
\hline $\begin{array}{l}\text { Aerosol } \\
\text { species }\end{array}$ & Winter & Spring & Summer & Fall \\
\hline WSON & $33 \pm 16$ & $28 \pm 13$ & $41 \pm 11$ & $20 \pm 10$ \\
Coarse $/ \mathrm{PM}_{10}(\%)$ & 50 & 50 & 83 & 55 \\
$\mathrm{NO}_{3}^{-}$ & $7 \pm 5$ & $15 \pm 12$ & $21 \pm 7$ & $9 \pm 8$ \\
$\mathrm{NH}_{4}^{+}$ & $10 \pm 12$ & $11 \pm 9$ & $24 \pm 16$ & $10 \pm 13$ \\
$\mathrm{nsSCa}^{2+}$ & $28 \pm 13$ & $28 \pm 13$ & $28 \pm 13$ & $41 \pm 11$ \\
Number of samples & 47 & 79 & 46 & 44 \\
\hline Meteorology & Winter & Spring & Summer & Fall \\
parameter & $11 \pm 3$ & $16 \pm 3$ & $27 \pm 12$ & $20 \pm 15$ \\
\hline$T\left({ }^{\circ} \mathrm{C}\right)$ & 78 & 118 & 0.5 & 132 \\
Rain (mm) & 16 & 16 & 2 & 15 \\
Number of rain events & & & &
\end{tabular}

region. In summer, the mean concentration of $\mathrm{NH}_{4}^{+}$was almost 2.4 times larger than all other seasons. The mean watersoluble $\mathrm{NO}_{3}^{-}$in summer was 1.4 higher than that of spring. High $\mathrm{NH}_{4}^{+}$and $\mathrm{NO}_{3}^{-}$concentrations in summer might be attributed again to the absence of rainfall and increase in incoming radiation. Similar results have been reported for the eastern Mediterranean (Bardouki et al., 2003).

\subsection{Influence of mineral dust episodes on WSON aerosol concentrations}

As is well documented, the eastern Mediterranean Sea is heavily impacted by mineral dust episodes originating from Sahara and Middle Eastern deserts (Kubilay and Saydam, 1995; Kubilay et al., 2000, Koçak et al., 2004a, b, 2012).

For the current study between March 2014 and April 2015, water-soluble non-sea salt calcium concentrations higher than $50 \mathrm{nmol} \mathrm{m}^{-3}$ (2000 $\mathrm{ng} \mathrm{m}^{-3}$ as a threshold value) were defined as mineral "dust events". These events were additionally confirmed using air mass back trajectories and OMI-AI. However, it is worth mentioning that for samples containing concentrations of $\mathrm{nssCa}^{2+}$ less than $50 \mathrm{nmol} \mathrm{m}^{-3}$, mineral dust transport from Sahara and Middle Eastern deserts to the sampling site may not be excluded, particularly in winter. Yet, the application of such an arbitrary value is inevitable since it provides simplicity to explore if there is any influence of mineral dust intrusion on WSON.

For example, one of the highest WSON concentrations $\left(66.1 \mathrm{nmol} \mathrm{N} \mathrm{m}^{-3}\right)$ was observed on 2 March 2014, when the air mass back trajectories were associated with south/southwesterly airflow. During this event, $\mathrm{nssCa}^{2+}$ and $\mathrm{NO}_{3}^{-}$showed a dramatic increase in their concentrations compared to the values observed during the previous day, reaching up to 429 and $60 \mathrm{nmol} \mathrm{m}^{-3}$, respectively. The OMI (Ozone Mapping Instrument) aerosol index (AI) and 3-day backward trajectory (1, 2, 3 and $4 \mathrm{~km}$ altitudes) air masses 

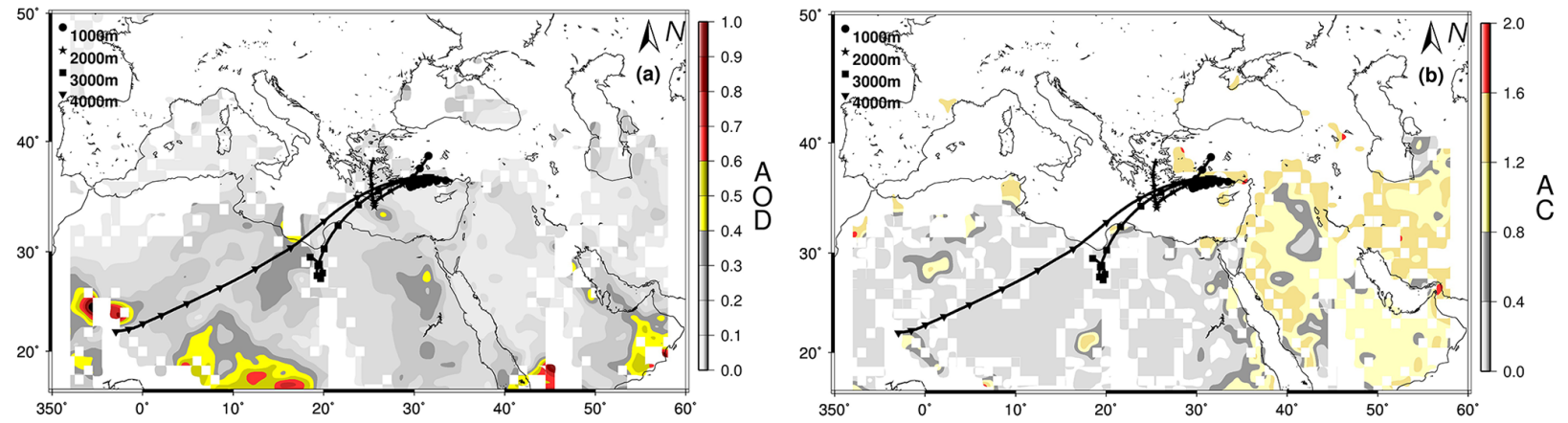

Figure 3. Three-day back trajectories showing the transport of air masses $1000 \mathrm{~m}$ (black circle), $2000 \mathrm{~m}$ (black star), $3000 \mathrm{~m}$ (black square) and $4000 \mathrm{~m}$ (black triangle) on 20 January 2015 for Erdemli. The aerosol optical depth (AOD, a) and Ångström component (AC, b) from MODIS (Moderate Resolution Imaging Spectroradiometer) distribution are also demonstrated with a color bar from grey to dark red.

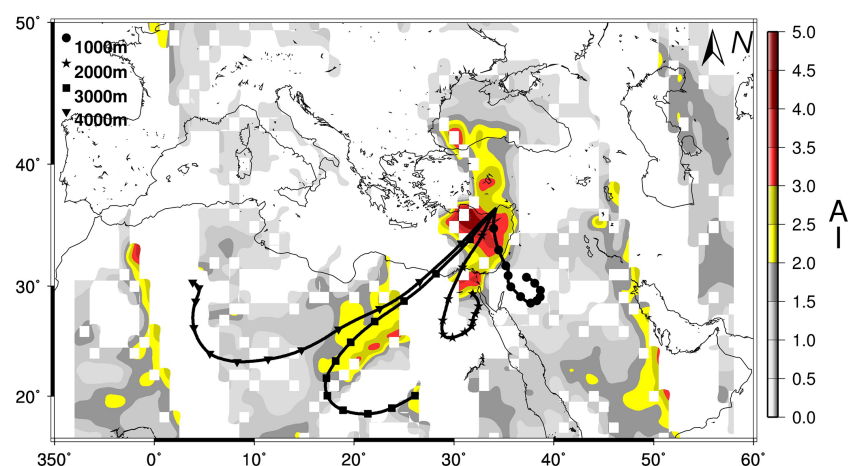

Figure 4. Three-day back trajectories indicating the transport of air masses $1000 \mathrm{~m}$ (black circle), $2000 \mathrm{~m}$ (black star), $3000 \mathrm{~m}$ (black square) and $4000 \mathrm{~m}$ (black triangle) on 2 March 2014 for Erdemli. The aerosol index (AI) from OMI (Ozone Mapping Instrument) distribution is also illustrated with a color bar from grey to dark red.

arriving at the Erdemli sampling site on 2 March 2014 are shown in Fig. 4. As can be seen from the figure, all air masses (except at $1 \mathrm{~km}$ altitude) originated from north Africa, whereas the back trajectory for $1 \mathrm{~km}$ altitude exhibited airflow from the Middle East. Hence, it is suggested that the sampling site was under the influence of mineral dust transport originating from desert regions located in the Middle East and north Africa. In support of this, the OMI-AI diagram clearly indicates a large dust plume over the eastern Mediterranean between coordinates $20-45^{\circ} \mathrm{N}$ and $15-40^{\circ} \mathrm{E}$. The aerosol index was found to be very high over the northeastern Mediterranean, ranging from 2.0 to 4.5. During this dust episode, $85 \%$ of the WSON was associated with the coarse fraction, which further supports mineral dust being a main source of water-soluble organic nitrogen.

Arithmetic mean concentrations together with corresponding standard deviations of WSON, $\mathrm{NO}_{3}^{-}, \mathrm{NH}_{4}^{+}$and $\mathrm{nsSCa}^{2+}$ for dust and non-dust events are presented in Fig. 5. As can be deduced from the diagram (except for $\mathrm{NH}_{4}^{+}$), WSON, $\mathrm{NO}_{3}^{-}$and $\mathrm{nssCa}^{2+}$ indicated a distinct difference between dust and non-dust events. Indeed, the application of the nonparametric Mann-Whitney U test indicated statistically significant differences between dust and non-dust events for WSON $(p<0.03), \mathrm{NO}_{3}^{-}(p<0.00002)$ and $\mathrm{nssCa}^{2+}$ $(p<0.000001)$, whereas no statistically significant difference was observed for $\mathrm{NH}_{4}^{+},(p=0.56)$. The crustally derived $\mathrm{nssCa}^{2+}$ and anthropologically derived $\mathrm{NO}_{3}^{-}$for dust events had arithmetic means of $95.8 \mathrm{nmol} \mathrm{m}^{-3}$ and $26.1 \mathrm{nmol} \mathrm{N} \mathrm{m}^{-3}$, which were almost 4 and 2 times higher than those observed for non-dust events, respectively. Such an increase in concentrations during dust events for these species has been previously reported in the eastern Mediterranean (Koçak et al., 2004b). Similarly, the arithmetic mean of WSON $\left(38.2 \mathrm{nmol} \mathrm{m}^{-3}\right)$ during dust events was 1.3 times higher compared to the value observed during nondust events $\left(29.4 \mathrm{nmol} \mathrm{m}^{-3}\right)$. Percent contributions of coarse WSON for dust and non-dust events were almost identical, being 58 and $60 \%$, respectively. A similar enrichment of WSON during dust events has been reported for Erdemli (Mace et al., 2003a), the Yellow Sea (Shi et al., 2010) and Finokalia (Violaki and Mihalopoulos, 2010). In addition, Griffin et al. (2007) have demonstrated a significant difference between dust and non-dust events for bacterial- and fungalcolony-forming units at Erdemli, the former being much greater. Thus, it might be speculated that this enhancement during dust events can be due to (a) mineral-dust-borne microorganisms, and/or (b) interaction (e.g., adsorption, acidbased reaction) between mineral dust and organic nitrogen compounds.

\subsection{Impact of airflow on WSON}

Arithmetic mean concentrations together with corresponding standard deviations for water-soluble nitrogen species and $\mathrm{nsSCa}^{2+}$ in aerosol samples according to categorized air mass sectors (at $1 \mathrm{~km}$ ) are presented in Table 5. WSON concentrations for the Middle East, north Africa and Turkey were comparable and arithmetic mean values were, respectively, 33, 36 and $32 \mathrm{nmol} \mathrm{m}^{-3}$. Correspondingly, mean 
Table 5. Arithmetic means along with standard deviations of WSON, $\mathrm{NO}_{3}^{-}, \mathrm{NH}_{4}^{+}\left(\mathrm{nmol} \mathrm{N} \mathrm{m}^{-3}\right)$ and $\mathrm{nssCa}^{2+}\left(\mathrm{nmol} \mathrm{m}^{-3}\right)$ in aerosol samples as a function of the classified airflow corresponding to 3-day air mass back trajectories reaching Erdemli.

\begin{tabular}{lrrrrr}
\hline Airflow & WSON & Coarse $/ \mathrm{PM}_{10}(\%)$ & $\mathrm{NO}_{3}^{-}$ & $\mathrm{NH}_{4}^{+}$ & $\mathrm{nssCa}^{2+}$ \\
\hline Middle East & $33 \pm 12$ & 61 & $12 \pm 12$ & $13 \pm 15$ & $48 \pm 71$ \\
North Africa & $36 \pm 16$ & 58 & $18 \pm 11$ & $12 \pm 14$ & $46 \pm 38$ \\
Turkey & $32 \pm 13$ & 63 & $15 \pm 10$ & $19 \pm 15$ & $23 \pm 9$ \\
Eastern Europe & $26 \pm 14$ & 49 & $10 \pm 9$ & $10 \pm 8$ & $21 \pm 9$ \\
Western Europe & $26 \pm 14$ & 48 & $10 \pm 8$ & $11 \pm 9$ & $20 \pm 7$ \\
Mediterranean Sea & $22 \pm 10$ & 27 & $10 \pm 8$ & $8 \pm 6$ & $19 \pm 8$ \\
\hline
\end{tabular}

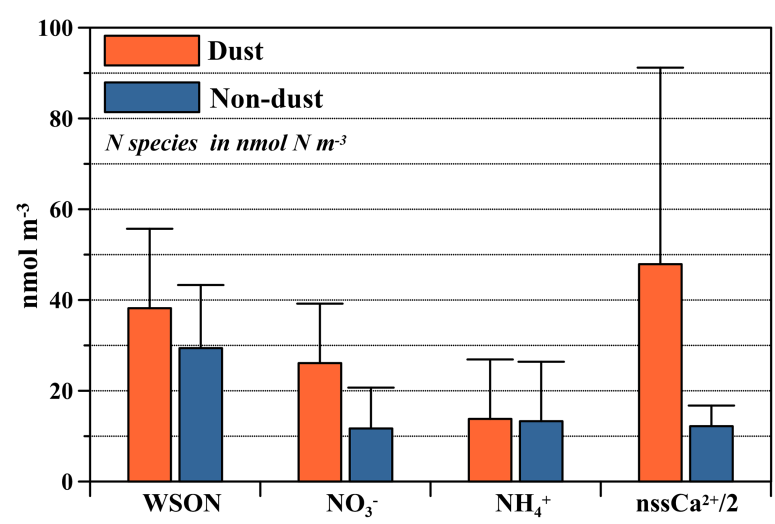

Figure 5. Arithmetic means together with corresponding standard deviations of WSON, $\mathrm{NO}_{3}^{-}, \mathrm{NH}_{4}^{+}$and $\mathrm{nssCa}^{2+}$ for dust and nondust events at the Erdemli site. Orange and blue bars denote arithmetic means for dust and non-dust, respectively. The black vertical line shows standard deviation.

WSON concentrations for eastern Europe, western Europe and the Mediterranean Sea were 26, 26 and $22 \mathrm{nmol} \mathrm{m}^{-3}$, being at least 1.2 times lower than those observed for the Middle East, north Africa and Turkey (Mann-Whitney U test, $p<0.05$ ). Coarse-mode contributions of WSON for air flow from the Middle East (61\%), north Africa (58\%) and Turkey $(63 \%)$ ranged from 58 to $63 \%$. However, lower coarsemode contributions were observed when air flow originated from eastern Europe (49\%), western Europe (48\%) and the Mediterranean Sea (27\%). The highest $\mathrm{NO}_{3}^{-}$concentrations were associated with airflow from north Africa and Turkey, with a value of 18 and $15 \mathrm{nmol} \mathrm{N} \mathrm{m}^{-3}$, respectively, and there was a statistically significant difference compared to the remaining air mass sectors $(p>0.05)$. The mean concentrations of $\mathrm{NO}_{3}^{-}$for air masses derived from north Africa and Turkey were at least 1.3 times larger than those calculated for the Middle East, eastern Europe, western Europe and Mediterranean Sea air sectors $(p>0.05)$. $\mathrm{NH}_{4}^{+}$had the highest concentration under the influence of airflow derived from Turkey. For this airflow, detected concentration was 1.5-2.4 times greater than that calculated for other air mass sectors. The Mann-Whitney U test showed that there was a statistically significant difference in the $\mathrm{nssCa}^{2+}$ concentrations.
Arithmetic mean concentrations of $\mathrm{nssCa}^{2+}$ in the Middle East and north Africa were approximately 2 times higher compared to the remaining air masses. As expected, these two airflows were primarily influenced by crustal material due to sporadic dust events originating from deserts located in north Africa and the Middle East.

\subsection{Source apportionment for WSON in aerosol}

A number of studies have discussed the possible sources of WSON in aerosol material by applying either simple correlation analyses (Mace et al., 2003a; Violaki and Mihalapoulos, 2010; Ho et al., 2015) or multivariate factor analyses (FA; Chen and Chen, 2010), including PMF (Chen et al., 2010). Usage of correlation analyses is useful when the numbers in sample populations are limited; however large datasets are required in order to carry out PMF and FA. Direct and indirect emissions of WSON from the sea surface have been demonstrated (Miyakazi et al., 2011; Altieri et al., 2016). Previous studies in the eastern Mediterranean have observed WSON to be associated with mineral dust (Mace et al., 2003a; Violaki and Mihalopoulos, 2010). As stated by Mace et al. (2003a), WSON might either have originated from mineral dust or might have been carried by dust events owing to adsorption of gaseous organic nitrogen compounds onto preexisting particles. In addition, Violaki and Mihalapoulos (2010) have shown fossil fuel and biomass burning as sources of WSON in the eastern Mediterranean atmosphere.

Figure 6 describes the potential sources of WSON by applying PMF 5.0. The predominant two factors were chiefly found to be related with WSTN. The first factor had a highloading for $\mathrm{NH}_{4}^{+}$with a value of 0.81 and a moderate loading of $\mathrm{SO}_{4}^{2-}(0.45)$. As expected, the factor contribution plot (not shown) indicated a summer maximum, demonstrating accumulation of these particles due to the absence of rain and enhanced gas-particle formation under the prevailing conditions (high temperature and solar radiation). The equivalent ratio of $\mathrm{NH}_{4}^{+}$and $\mathrm{SO}_{4}^{2-}$ for this factor was 0.79 , indicating $\left(\mathrm{NH}_{4}\right) \mathrm{HSO}_{4}$ formation (Koçak et al., 2007). A total of $60 \%$ of the air mass trajectories was found to be originated from Turkey when the first highest $20 \%$ of the fac- 


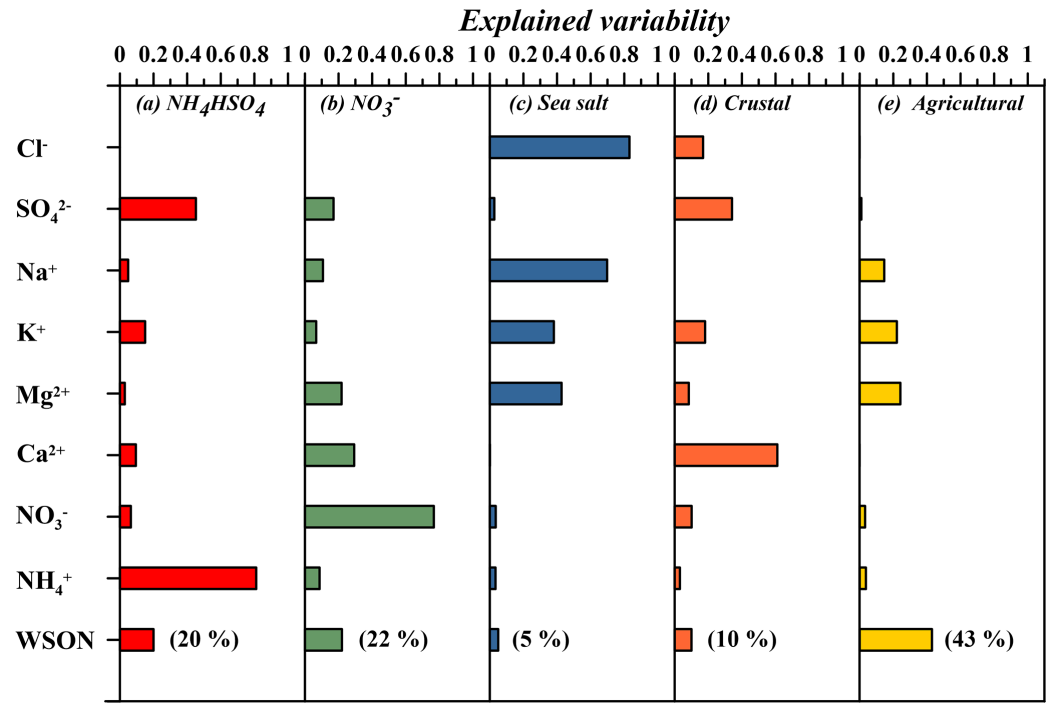

Figure 6. Source apportionment of WSON from positive matrix factorization for $\mathrm{PM}_{10}$ at Erdemli.

tor loading were considered. Consequently, this factor might principally be ascribed to regional sources such as urban agglomerations (Ankara, İzmir and İstanbul) and industrial activities (particularly the Marmara region). The second factor explained $77 \%$ of the $\mathrm{NO}_{3}^{-}$variation and described 17 and $10 \%$ of the $\mathrm{SO}_{4}^{2-}$ and $\mathrm{NH}_{4}^{+}$variation, respectively. This group was also associated with cations such as $\mathrm{Na}^{+}(11 \%)$, $\mathrm{K}^{+}(7 \%), \mathrm{Mg}^{2+}(22 \%)$ and $\mathrm{Ca}^{2+}(29 \%)$, implying reactions mainly between acidic nitrate and alkaline species. It has been shown that emissions of $\mathrm{Cl}^{-}$and $\mathrm{NO}_{3}^{-}$result from motor vehicles (Lim at al., 2010). Taking into account the absence of $\mathrm{Cl}^{-}$, this factor may be attributed to combustion. The first and second factors accounted for 20 and $22 \%$ of the variability in WSON, respectively. It might, therefore, be argued that the variability of WSON in the first group resulted from the reaction between volatile organic $\mathrm{N}$ and ammonium sulfate aerosols, whilst the variability of WSON explained by the second factor was as a result of the reaction between volatile organic compounds and $\mathrm{NO}_{x}$ and/or neutralization of acidic nitrate by alkaline nitrogen-containing compounds such as urea and amine. The third factor was heavily influenced by $\mathrm{Cl}^{-}(0.8)$ and $\mathrm{Na}^{+}(0.70)$, while it was moderately impacted by $\mathrm{Mg}^{2+}$ and $\mathrm{K}^{+}$. This factor is likely due to sea salt formation. The fourth factor was predominantly impacted by $\mathrm{Ca}^{2+}$ and hence may be attributed to crustal material. Crustal sources explained $10 \%$ of the WSON variability. The final defined factor had a moderate loading of WSON $(E V=0.43$, explained $43 \%)$ while it was affiliated with $\mathrm{Na}^{+}(0.15), \mathrm{K}^{+}(0.22)$ and $\mathrm{Mg}^{2+}(0.24)$. The factor contribution diagram shows the highest values to be in summer (not shown) and hence it can be attributed to resuspension of the soil particularly affected by intense agricultural activities.

\subsection{Atmospheric depositions of $\mathrm{N}$ species and implications regarding marine production}

The atmospheric dry $\left(n=337 ; 21.3 \mathrm{mmol} \mathrm{N} \mathrm{m}^{-2} \mathrm{yr}^{-1}\right)$ and wet $\left(n=23 ; 36.7 \mathrm{mmol} \mathrm{N} \mathrm{m}^{-2} \mathrm{yr}^{-1}\right)$ deposition fluxes of WSON, $\mathrm{NO}_{3}^{-}, \mathrm{NH}_{4}^{+}$and WSTN from March 2014 and April 2015 are demonstrated in Table 6. The atmospheric deposition of water-soluble total nitrogen $\left(57.8 \mathrm{mmol} \mathrm{N} \mathrm{m}^{-2} \mathrm{yr}^{-1}\right)$ was chiefly originated from wet deposition $\left(36.7 \mathrm{mmol} \mathrm{N} \mathrm{m}^{-2} \mathrm{yr}^{-1}\right)$, amounting to $63 \%$ of the total atmospheric deposition. This difference might be attributed to the water-soluble ammonium; for instance, the atmospheric deposition of $\mathrm{NH}_{4}^{+}\left(15.6 \mathrm{mmol} \mathrm{N} \mathrm{m}^{-2} \mathrm{yr}^{-1}\right)$ was dominated by wet deposition, contributing $92 \%$ of the total ammonium atmospheric flux. In contrast, the atmospheric fluxes of WSON and $\mathrm{NO}_{3}^{-}$were more or less equally influenced by both deposition modes. Corresponding WSON $\left(9.8 \mathrm{mmol} \mathrm{N} \mathrm{m}^{-2} \mathrm{yr}^{-1}\right)$ and $\mathrm{NO}_{3}^{-}$ $\left(10.0 \mathrm{mmol} \mathrm{N} \mathrm{m}^{-2} \mathrm{yr}^{-1}\right)$ contributions to dry deposition were found to be 46 and $48 \%$ respectively. In contrast, $\mathrm{NH}_{4}^{+}\left(1.3 \mathrm{mmol} \mathrm{N} \mathrm{m}^{-2} \mathrm{yr}^{-1}\right)$ was only estimated to contribute $6 \%$ of the total deposition. Wet deposition of nitrogen was impacted by WSON $\left(10.8 \mathrm{mmol} \mathrm{N} \mathrm{m}^{-2} \mathrm{yr}^{-1}\right), \mathrm{NO}_{3}^{-}$ (11.7 $\left.\mathrm{mmol} \mathrm{N} \mathrm{m}^{-2} \mathrm{yr}^{-1}\right)$, and $\mathrm{NH}_{4}^{+}\left(14.3 \mathrm{mmol} \mathrm{N} \mathrm{m}^{-2} \mathrm{yr}^{-1}\right)$ in the increasing order $29 \%<32 \%<39 \%$. On average, WSON accounted for $36 \%$ of the total atmospheric deposition of WSTN. The atmospheric deposition of the dissolved inorganic nitrogen $\left(\mathrm{DIN}=37.3 \mathrm{mmol} \mathrm{N} \mathrm{m}^{-2} \mathrm{yr}^{-1}\right.$ ) was found to decrease about $45 \%$ compared to the value reported by Koçak et al. (2010, DIN $=70 \mathrm{mmol} \mathrm{N} \mathrm{m}^{-2} \mathrm{yr}^{-1}$ ). The reason for this decrease is beyond the scope of this article; nonetheless, there is a need to understand how the DIN flux changed from the beginning of the 2000s to 2015 . 
Table 6. Atmospheric dry ( 337 samples) and wet ( 23 samples) deposition of WSON, $\mathrm{NO}_{3}^{-}, \mathrm{NH}_{4}^{+}$and WSTN together with their relative contributions at Erdemli during the period of March 2014 to April 2015.

\begin{tabular}{lrr}
\hline Species & $\begin{array}{r}F_{\mathrm{d}} \\
\left(\mathrm{mmol} \mathrm{N} \mathrm{m}^{-2} \mathrm{yr}^{-1}\right)\end{array}$ & $\begin{array}{r}\text { Relative } \\
\text { contribution }\end{array}$ \\
\hline WSON & 9.8 & 46 \\
$\mathrm{NO}_{3}^{-}$ & 10.0 & 48 \\
$\mathrm{NH}_{4}^{+}$ & 1.3 & 6 \\
WSTN & 21.1 & \\
\hline Species & $F_{\mathrm{W}}$ & Relative \\
& $\left(\mathrm{mmol} \mathrm{N} \mathrm{m}^{-2} \mathrm{yr}^{-1}\right)$ & contribution \\
\hline WSON & 10.7 & 29 \\
$\mathrm{NO}_{3}^{-}$ & 11.7 & 32 \\
$\mathrm{NH}_{4}^{+}$ & 14.3 & 39 \\
$\mathrm{WSTN}$ & 36.7 & \\
\hline
\end{tabular}

\section{Summary}

In the current study, water-soluble organic nitrogen in aerosol and rain samples obtained over the eastern Mediterranean has been investigated. From this investigation the following summary may be made.

1. Of the nitrogen species, aerosol WSON $\left(23.8 \pm 16.3 \mathrm{nmol} \mathrm{N} \mathrm{m}^{-3}\right) \quad$ exhibited the highest arithmetic mean, followed by ammonium $\left(23.3 \pm 14.4 \mathrm{nmol} \mathrm{N} \mathrm{m}^{-3}\right)$ and then nitrate $\left(17.9 \pm 15.7 \mathrm{nmol} \mathrm{N} \mathrm{m}^{-3}\right)$. Aerosol WSON was mainly associated with coarse particles $(66 \%)$. The WSTN was equally influenced by WSON and $\mathrm{NH}_{4}^{+}$, each contributing 37 and $35 \%$, respectively, whereas the contribution to WSTN of $\mathrm{NO}_{3}^{-}$was $28 \%$. In rainwater, the VWM concentrations of water-soluble nitrogen species were comparable. WSON and $\mathrm{NO}_{3}^{-}$accounted for 29 and $32 \%$ of the WSTN, whilst $\mathrm{NH}_{4}^{+}$elucidated $39 \%$ of the WSTN.

2. Aerosol WSON concentrations exhibited large variation from one day to another day. Generally, lower concentrations were observed during rainy days. Higher concentrations of aerosol WSON were associated with different airflow. The three highest concentrations were related to (i) mineral dust transport from Sahara and Middle Eastern deserts, (ii) north/northwesterly airflow from Turkey's largest cultivated plain, Konya, and (iii) mid-range pollution transport from the Turkish coast.
3. Influence of mineral dust transport on aerosol WSON concentrations was assessed. The crustally derived $\mathrm{nssCa}^{2+}$ and anthropogenic $\mathrm{NO}_{3}^{-}$for dust events had arithmetic means of $95.8 \mathrm{nmol} \mathrm{m}^{-3}$ and $26.1 \mathrm{nmol} \mathrm{N} \mathrm{m}{ }^{-3}$, which were almost 4 and 2 times higher than those of observed for non-dust events. The arithmetic mean of WSON $\left(38.2 \mathrm{nmol} \mathrm{m}^{-3}\right)$ for dust events was 1.3 times higher compared to that observed for non-dust events $\left(29.4 \mathrm{nmol} \mathrm{m}^{-3}\right)$.

4. Source apportionment suggested that aerosol WSON was mainly originated from anthropogenic sources, including agricultural (43\%), secondary aerosols (20\%) and nitrate $(22 \%)$; whereas the two natural sources, crustal material $(10 \%)$ and sea salts $(5 \%)$, contributed $15 \%$ to the WSON.

5. The total atmospheric deposition of water-soluble nitrogen $\left(57.8 \mathrm{mmol} \mathrm{N} \mathrm{m}^{-2} \mathrm{yr}^{-1}\right)$ was mainly via wet deposition ( $36.7 \mathrm{mmol} \mathrm{N} \mathrm{m}^{-2} \mathrm{yr}^{-1}$ ). In contrast, the atmospheric fluxes of WSON and $\mathrm{NO}_{3}^{-}$were equally influenced by the dry and wet deposition modes. On average, WSON accounted for $36 \%$ of the total atmospheric deposition of WSTN. From the beginning of the 2000s to 2015 , the atmospheric deposition of the dissolved inorganic nitrogen declined about $45 \%$; as a consequence there is a need to understand how the DIN flux changed.

Data availability. Data are available upon request to the corresponding author. 


\section{Appendix A}

In this section, the authors briefly summarize the main features of the positive matrix factorization (PMF).

The PMF receptor model was described in detail by Paatero and Tapper (1994) and the EPA PMF 5.0 User Guide. The details of the algorithm are also provided by the EPA PMF 5.0 User Guide. This multivariate tool decomposes the data matrix (X: $n$ rows in other words number of samples and $m$ columns: number of species) into two matrices: (i) source contributions $(\mathbf{G}=n \times p)$ and (ii) source profiles $(\mathbf{F}=p \times m)$. This can be given as follows:

$\mathbf{X}=\mathbf{G F}+E$,

where $E$ and $p$ denote the residual part and the number of factors extracted, respectively.

In order to run PMF, two input files are needed: (i) concentration and (ii) uncertainty. The first file includes concentrations, whilst the second file contains uncertainty for each species. Uncertainty for PMF application can be calculated using different approaches such as an ad hoc formula (Anttila et al., 1995), a fixed fraction of the concentration (Paatero et al., 2014) or a more complicated way, as proposed by Polissar et al. (1998). No matter how it is calculated, if uncertainty is too high for one parameter, species will be categorized as bad by the PMF. For example, the precision of WSON for this study was found to be almost 3 times more than that of the arithmetic mean. If one uses Eq. (3) to calculate the uncertainty of WSON for each data point, then it will be omitted by PMF, causing very high uncertainty values. Consequently, there will be no source apportionment for WSON. In order to obtain reasonable factor profiles for WSON, a twostep procedure was proposed. First, Eq. (3) is used to eliminate WSON samples when their corresponding precisions are lower than a mean $R$ value of 0.3 (see Eq. 4). Second, the uncertainty is set to a higher value for WSON (15\%) compared to the remaining species (5\%) since WSON inevitably exhibits very low precision (see Eqs. 1 and 3).

After the base run one has to estimate the quality of the obtained results from PMF (for more details, see the EPA PMF 5.0 User Guide and Paatero et al., 2014). Base model displacement (DISP), bootstrap (BS) and bootstrap displacement (BS-DISP) methods are the main tools of assessing quality. It has been demonstrated that these three methods complement each other (for more details, see Paatero et al., 2014). EFA PMF 5.0 provides aerosol data obtained from Baltimore and guides the applicant step by step to robustly use the source apportionment program of EPA PM 5.0. More details are given in the EFA 5.0 User Guide, and this is accessible to the scientific community. 
Author contributions. MK developed the concept and designed the study. MN and MK performed the experiments, analyzed the data and prepared the manuscript.

Competing interests. The authors declare that they have no conflict of interest.

Special issue statement. This article is part of the special issue "CHemistry and AeRosols Mediterranean EXperiments (ChArMEx) (ACP/AMT inter-journal SI)". It is not associated with a conference.

Acknowledgements. This work was mainly supported by the Scientific and Technological Research Council of Turkey (TUBITAK). Required data were collected within the framework of the TUBITAK 113 Y107 project. This study was also supported by the DEKOSIM (Center for Marine Ecosystem and Climate Research) Project (BAP-08-11-DPT.2012K120880) funded by the Ministry of Development of Turkey. We would like to thank Ersin Tursak, Pınar Kalegeri and Merve Açıyol for helping during sample collection and analysis. Aerosol optical thickness, Ångström component and aerosol index values used in this study were produced with the Giovanni online data system and developed and maintained by the NASA GES DISC. We also acknowledge the MODIS and OMI mission scientists and associated NASA personnel for the production of the data used in this research effort. The authors would like to thank the two anonymous reviewers for their helpful comments which greatly improved the submitted manuscript.

Edited by: Evangelos Gerasopoulos

Reviewed by: two anonymous referees

\section{References}

Altieri, K., Fawcett, S., Peters, A., Sigman, D., and Hastings, M.: Marine biogenic source of atmospheric organic nitrogen in the subtropical North Atlantic, P. Natl. Acad. Sci. USA, 113, 925930, 2016.

Anttila, P., Paatero, P., Tapper, U., and Järvinen, O.: Source identification of bulk wet deposition in Finland by positive Matrix Factorization, Atmos. Environ., 14, 1705-1718, 1995.

Bardouki, H., Liakakou, H., Economou, C., Sciare, J., Smolik, J., Zdimal, V., Eleftheriadis, K., Lazaridis, M., Dye, C., and Mihalopoulos, N.: Chemical composition of size resolved atmospheric aerosols in the eastern Mediterranean during summer and winter, Atmos. Environ., 37, 195-208, 2003.

Cape, J. N., Kirika, A., Rowland, A. P., Wilson, D. R., Jickells, T. D., and Cornell, S: Organic nitrogen in precipitation: real problem or sampling artefact?, The Scientific World, 1, 230-237, 2001.

Cape, J. N., Cornell, S. E., Jickells, T. D., and Nemitz, E.: Organic nitrogen in the atmosphere - Where does it come from? A review of sources and methods, Atmos. Res., 102, 30-48, 2011.
Chen, H. and Chen, L.: Occurrence of water soluble organic nitrogen in aerosols at a coastal area, J. Atmos. Chem., 65, 49-71, https://doi.org/10.1007/s10874-010-9181-y, 2010.

Chen, H., Chen, L., Chiang, Z., Hung, C., Lin, F., Chou, W., Gong, G., and Wen, L.: Size fractionation and molecular composition of water-soluble inorganic and organic nitrogen in aerosols of a coastal environment, J. Geophys. Res., 115, D22307, https://doi.org/10.1029/2010JD014157, 2010.

Cornell, S., Rendell, A., and Jickells, T.: Atmospheric inputs of dissolved organic nitrogen to the oceans, Nature, 376, 243-246, 1995.

Cornell, S., Jickells, T., and Thornton, C.: Urea in rainwater and atmospheric aerosol, Atmos. Environ., 32, 1903-1910, 1998.

Cornell, S., Mace, K., Coeppicus, S., Duce, R., Huebert, B., Jickells, T., and Zhuang, L. Z.: Organic nitrogen in Hawaiian rain and aerosols, J. Geophys. Res., 106, 7973-7983, 2001.

Cornell, S. E., Jickells, T. D., Cape, J. N., Rowland, A. P., and Duce, R. A.: Organic nitrogen deposition on land and coastal environments: a review of methods and data, Atmos. Environ., 37, 2173 2191, 2003.

De Haan, D. O., Hawkins, L. N., Kononenko, J. A., Turley, J. J., Corrigan, A. L., Tolbert, M. A., and Jimenez, J. L.: Formation of Nitrogen-Containing Oligomers by Methylglyoxal and Amines in Simulated Evaporating Cloud Droplets, Environ. Sci. Technol., 45, 948-991, 2011.

Draxler, R. R. and Rolph, G. D.: HYSPLIT (HYbrid Single-Particle Lagrangian Integrated Trajectory), Model Access via NOAA ARL READY Website, NOAA Air Resources Laboratory, Silver Spring, MD, available at: https://ready.arl.noaa.gov/HYSPLIT. php (last access: 28 February 2018), 2003.

Duce, R. A., Liss, P. S., Merrill, J. T., Atlas, E. L., and Buat-Menard, P.: The atmospheric input of trace species to the world ocean, Global Biogeochem. Cy., 5, 193-259, 1991.

Duce, R. A., LaRoche, J., Altieri, K., Arrigo, K. R., Baker, A. R., Capone, D. G., Cornell, S., Dentener, F., Galloway, J., Ganeshram, R. S., Geider, R. J., Jickells, T., Kuypers, M. M., Langlois, R., Liss, P. S., Liu, S. M., Middelburg, J. J., Moore, C. M., Nickovic, S., Oschlies, A., Pedersen, T., Prospero, J., Schlitzer, R., Seitzinger, S., Sorensen, L. L., Uematsu, M., Ulloa, O., Voss, M., Ward, B., and Zamora, L.: Impacts of atmospheric anthropogenic nitrogen on the open ocean, Science, 320 , 893-897, 2008.

Galloway, J. and Cowling, E.: Reactive nitrogen and the world: 200 years of change, Ambio, 31, 64-71, 2002.

Galloway, J. N., Townsend, A. R., Erisman, J. W., Bekunda, M., Cai, Z. C., Freney, J. R., Martinelli, L. A., Seitzinger, S. P., and Sutton, M. A.: Transformation of the nitrogen cycle: Recent trends, questions, and potential solutions, Science, 320, 889-892, 2008.

Galloway, M. M., Chhabra, P. S., Chan, A. W. H., Surratt, J. D., Flagan, R. C., Seinfeld, J. H., and Keutsch, F. N.: Glyoxal uptake on ammonium sulphate seed aerosol: reaction products and reversibility of uptake under dark and irradiated conditions, Atmos. Chem. Phys., 9, 3331-3345, https://doi.org/10.5194/acp-93331-2009, 2009.

Ge, X., Wexler, A., and Clegg, S.: Atmospheric amines e part I. A review, Atmos. Environ., 45, 524-546, 2011.

Glibert, P. M., Trice, T. M., Michael, B., and Lane, L.: Urea in the tributaries of the Chesapeake and coastal bays of Maryland, Water Air Soil Poll., 43, 160-229, 2005. 
Griffin, D. W., Kubilay, N., Koçak, M., Gray, M. A., Borden, T. C., and Shinn, E.: Airborne desert dust and aeromicrobiology over the Turkish Mediterranean coastline, Atmos. Environ., 41, 40504062, 2007.

Hamad, N., Millot, C., and Taupier-Letage, I.: A new hypothesis about the surface circulation in the eastern basin of the Mediterranean Sea, Prog. Oceanogr., 66, 287-298, 2005.

Hansell, D.: Results and observations from the measurement of DOC and DON in seawater using a high-temperature catalytic oxidation technique, Mar. Chem., 41, 195-202, 1993.

Herut, B., Krom, M. D., Pan, G., and Mortimer, R.: Atmospheric input of nitrogen and phosphorus to the Southeast Mediterranean: sources, fluxes, and possible impact, Limnol. Oceanogr., 44, 1683-1692, 1999.

Herut, B., Collier, R., and Krom, M. D.: The role of dust in supplying nitrogen and phosphorus to the Southeast Mediterranean, Limnol. Oceanogr., 47, 870-878, 2002.

Ho, K., Ho, S. S., Huang, R., Liu, S., Cao, J., Zhang, T., Chuang H., Chan, C. S., Hu, D., and Tian, L.: Characteristics of water-soluble organic nitrogen in fine particulate matter in the continental area of China, Atmos. Environ., 106, 252-261, 2015.

Hopke, P. K., Xie, Y., Raunemaa, T., Biegalski, S., Landsberger, S., Maenhaut, W., Artaxo, P., and Cohen, D.: Characterization of the Gent Stacked Filter Unit PM 10 Sampler, Aerosol Sci. Tech., 27, 726-735, 1997.

Huang, S., Rahn, K. A., and Arimoto, R.: Testing and optimizing two factor analysis techniques on aerosol at Narragansett, Rhode Island, Atmos. Environ., 33, 2169-2185, 1999.

Jickells, T. D., Buitenhuis, E., Altieri, K., Baker, A. R., Capone, D., Duce, R. A., Dentener, F., Fennel, K., Kanakidou, M., LaRoche, J., Lee, K., Liss, P., Middelburg, J. J., Moore, J. K., Okin, G., Oschlies, A., Sarin, M., Seitzinger, S., Sharples, J., Singh, A., Suntharalingam, P., Uematsu, M., and Zamora, L. M.: A reevaluation of the magnitude and impacts of anthropogenic atmospheric nitrogen inputs on the ocean, Global Biogeochem. Cy., 31, 289305, https://doi.org/10.1002/2016GB005586, 2017.

Keene, W., Montag, J., Maben, J., Southwell, M., Leonard, J., Church, T., Moody, J., and Galloway, J.: Organic nitrogen in precipitation over Eastern North America, Atmos. Environ., 36, 4529-4540, 2002.

Koçak, M., Nimmo, M., Kubilay, N., and Herut, B.: Spatio-temporal aerosol trace metal concentrations and sources in the Levantine Basin of the Eastern Mediterranean, Atmos. Environ., 38, 21332144, 2004a.

Koçak, M., Kubilay, N., and Mihalopoulos, N.: Ionic composition of lower tropospheric aerosols at a Northeastern Mediterranean site: implications regarding sources and long-range transport, Atmos. Environ., 38, 2067-2077, 2004b.

Koçak, M., Mihalopoulos, N., and Kubilay, N.: Chemical composition of the fine and coarse fraction of aerosols in the Northeastern Mediterranean, Atmos. Environ., 41, 7351-7368, 2007.

Koçak, M., Mihalopoulos, N., and Kubilay, N.: Source regions of $\mathrm{PM}_{10}$ in the Eastern Mediterranean atmosphere, Atmos. Res., 92, 464-474, 2009.

Koçak, M., Kubilay, N., Tugrul, S., and Mihalopoulos, N.: Atmospheric nutrient inputs to the northern levantine basin from a long-term observation: sources and comparison with riverine inputs, Biogeosciences, 7, 4037-4050, https://doi.org/10.5194/bg7-4037-2010, 2010.
Koçak, M., Theodosi, C., Zarmpas, P., Seguret, M. J. M., Herut, B., Kallos, G., Mihalopoulos, N., Kubilay, N., and Nimmo, M.: Influence of mineral dust transport on the chemical composition and physical properties of the Eastern Mediterranean aerosol, Atmos. Environ., 57, 266-277, 2012.

Krom, M. D., Brenner, S., Kress, N., and Gordon, L. I.: Phosphorus limitation of primary productivity in the E. Mediterranean sea, Limnol. Oceanogr., 36, 424-432, 1991.

Krom, M. D., Herut, B., and Mantoura, R. F. C.: Nutrient budget for the Eastern Mediterranean: implications for P limitation, Limnol. Oceanogr., 49, 1582-1592, 2004.

Krom, M. D., Emeis, K.-C., and Van Cappellen, P.: Why is the Eastern Mediterranean phosphorus limited?, Prog. Oceanogr., 85, 236-244, 2010.

Kubilay, N. and Saydam, C.: Trace elements in atmospheric particulates over the Eastern Mediterranean: concentration, sources and temporal variability, Atmos. Environ., 29, 2289-2300, 1995.

Kubilay, N., Nickovic, S., Moulin, C., and Dulac, F.: An illustration of the transport and deposition of mineral dust onto the eastern Mediterranean, Atmos. Environ., 34, 1293-1303, 2000.

Lee, E., Chan, C. K., and Paatero, P.: Application of positive matrix factorization in source apportionment of particulate pollutants in Hong Kong, Atmos. Environ., 33, 3201-3212, 1999.

Lim, J. M., Lee, J. H., Moon, J. H., Chung, Y. S., and Kim, K. H.: Source apportionment of $\mathrm{PM}_{10}$ at a small industrial area using positive matrix factorization, Atmos. Res., 95, 88-100, 2010.

Ludwig, W., Dumont, E., Meybeck, M., and Heussner, S.: River discharges of water and nutrients to the Mediterranean and Black Sea: Major drivers for ecosystem changes during past and future decades?, Prog. Oceanogr., 80, 199-217, 2009.

Mace, K. A., Kubilay, N., and Duce, R. A.: Organic nitrogen in rain and aerosol in the eastern Mediterranean atmosphere: An association with atmospheric dust, J. Geophys. Res., 108, 4320, https://doi.org/10.1029/2002JD002997, 2003a.

Mace, K. A., Duce, R. A., and Tindale, N. W.: Organic nitrogen in rain and aerosol at Cape Grim, Tasmania Australia, J. Geophys. Res., 108, 4338, https://doi.org/10.1029/2002JD003051, 2003 b.

Mace, K. A., Artaxo, P., and Duce, R.: Water-soluble organic nitrogen in Amazon Basin aerosols during the dry (biomass burning) and wet seasons, J. Geophys. Res., 108, 4512, https://doi.org/10.1029/2003JD003557, 2003c.

Markaki, Z., Oikonomou, K., Koçak, M., Kouvarakis, G., Chaniotaki, A., Kubilay, N., and Mihalopoulos, N.: Atmospheric deposition of inorganic phosphorus in the Levantine Basin, eastern Mediterranean: Spatial and temporal variability and its role in seawater productivity, Limnol. Oceanogr., 48, 1557-1568, https://doi.org/10.4319/lo.2003.48.4.1557, 2003.

Markaki, Z., Loÿe-Pilot, M. D., Violaki, K., Benyahya, L., and Mihalopoulos, N.: Variability of atmospheric deposition of dissolved nitrogen and phosphorus in the Mediterranean and possible link to the anomalous seawater N / P ratio, Mar. Chem., 120, 187-194, https://doi.org/10.1016/j.marchem.2008.10.005, 2010.

Mihalopoulos, N., Kerminen, V. M., Kanakidou, M., Berresheim, H., and Sciare, J.: Formation of particulate sulfur species (sulfate and methanesulfonate) during summer over the Eastern Mediterranean: a modelling approach, Atmos. Environ., 41, 6860-6871, 2007.

Miller, J.: The nitrogen content of rain falling at Rothamsted, J. Agr. Sci., 1, 280-303, 1905. 
Miyazaki, Y., Kawamura, K., Jung, J., Furutani, H., and Uematsu, M.: Latitudinal distributions of organic nitrogen and organic carbon in marine aerosols over the western North Pacific, Atmos. Chem. Phys., 11, 3037-3049, https://doi.org/10.5194/acp11-3037-2011, 2011.

Neff, J. C., Holland, E. A., Dentener, F. J., McDowell, W. H., and Russell, K. M.: The origin, composition and rates of organic nitrogen deposition: A missing piece of the nitrogen cycle. Biogeochemistry, 57, 99-136, 2002.

Paatero, P. and Tapper, U.: Positive matrix factorization: a nonnegative factor model with optimal utilization of error estimates of data value, Environmetrics, 5, 111-126, 1994.

Paatero, P., Eberly, S., Brown, S. G., and Norris, G. A.: Methods for estimating uncertainty in factor analytic solutions, Atmos. Meas. Tech., 7, 781-797, https://doi.org/10.5194/amt-7781-2014, 2014.

Peierls, B. L. and Paerl, H. W.: Bioavailability of atmospheric organic nitrogen deposition to coastal phytoplankton, Limnol. Oceanogr., 42, 1819-1823, 1997.

Polissar, A. V., Hopke, P. K., Paatero, P., Malm, W. C., and Sisler, J. F.: Atmospheric aerosol over Alaska 2. Elemental composition and sources, J. Geophys. Res., 103, 19045-19057, 1998.

Powley, H. R., Krom, M. D., and Van Cappellen, P.: Understanding the unique biogeochemistry of the Mediterranean Sea: Insights from a coupled phosphorus and nitrogen model, Global Biogeochem. Cy., 31, 1010-1031, https://doi.org/10.1002/2017GB005648, 2017.

Seitzinger, S. P. and Sanders, R. W.: Atmospheric inputs of dissolved organic nitrogen stimulate estuarine bacteria and phytoplankton, Limnol. Oceanogr., 44, 721-730, 1999.

Shi, J. H., Gao, H. W., Qi, J. H., Zhang, J., and Yao, X. H.: Sources, compositions, and distributions of water-soluble organic nitrogen in aerosols over the China Sea, J. Geophys. Res., 115, D17303, https://doi.org/10.1029/2009JD013238, 2010.

Sorooshian, A., Murphy, S. M., Hersey, S., Gates, H., Padro, L. T., Nenes, A., Brechtel, F. J., Jonsson, H., Flagan, R. C., and Seinfeld, J. H.: Comprehensive airborne characterization of aerosol from a major bovine source, Atmos. Chem. Phys., 8, 5489-5520, https://doi.org/10.5194/acp-8-5489-2008, 2008.

Spokes, L. J., Jickells, T. D., and Jarvis, K.: Atmospheric inputs of trace metals to the northeast Atlantic Ocean: the importance of south-easterly flow, Mar. Chem., 76, 319-330, 2001.

Surratt, J. D., Gómez-González, Y., Chan, A. W. H., Vermeylen, R., Shahgholi, M., Kleindienst, T. E., Edney, E. O., Offenberg, J. H., Lewandowski, M., Jaoui, M., Maenhaut, Claeys, W. M., Flagan, R. C., and Seinfeld, J. H.: Organosulfate Formation in Biogenic Secondary Organic Aerosol, J. Phys. Chem. A, 112, 8345-8378, 2008.

Timperley, M. H., Vigor-Brown, R. J., Kawashima, M., and Ishigami, M.: Organic nitrogen compounds in atmospheric precipitation: their chemistry and availability to phytoplankton, Can. J. Fish Aquat. Sci., 42, 1171-1177, 1985.
Twohy, C. H., Petters, M. D., Snider, J. R., Stevens, B., Tahnk, W., Wetzel, M., Russell, L., and Burnet, F.: Evaluation of the aerosol indirect effect in marine stratocumulus clouds: Droplet number, size, liquid water path, and radiative impact, J. Geophys. Res., 110, D08203, https://doi.org/10.1029/2004JD005116, 2005.

US EPA: EPA/600/R-14/108, available at: https://www.epa.gov/ sites/production/files/2015-02/documents/pmf_5.0_user_guide. pdf (last access: 8 March 2018), 2014.

Viana, M., Pandolfi, M., Minguillon, M. C., Querol, X., Alastuey, A., Monfort, E., and Celades, I.: Inter-comparison of receptor models for PM sources apportionment: case study in an industrial area, Atmos. Environ., 42, 3820-3832, 2008.

Violaki, K. and Mihalopoulos, N.: Water-soluble organic nitrogen (WSON) in size-segregated atmospheric particles over the Eastern Mediterranean, Atmos. Environ., 44, 4339-4345, 2010.

Violaki, K., Zarbas, P., and Mihalopoulos, N.: Long-term measurements of dissolved organic nitrogen (DON) in atmospheric deposition in the Eastern Mediterranean: fluxes, origin and biogeochemical implications, Mar. Chem., 120, 179-186, 2010.

Violaki, K., Sciare, J., Williams, J., Baker, A. R., Martino, M., and Mihalopoulos, N.: Atmospheric water-soluble organic nitrogen (WSON) over marine environments: a global perspective, Biogeosciences, 12, 3131-3140, https://doi.org/10.5194/bg-123131-2015, 2015.

Yılmaz, A. and Tuğrul, S.: The effect of cold- and warm-core eddies on the distribution and stoichiometry of dissolved nutrients in the northeastern Mediterranean, J. Marine Syst., 16, 253-268, 1998.

Yu, G., Bayer, A. R., Galloway, M. M., Korshavn, K. J., Fry, C. G., and Keutsch, F. N.: Glyoxal in Aqueous Ammonium Sulfate Solutions: Products, Kinetics and Hydration Effects, Environ. Sci. Technol., 45, 6336-6342, https://doi.org/10.1021/es200989n, 2011.

Yücel, N.: Monthly changes in primary and bacterial productivity in the north-eastern Mediterranean shelf waters, $\mathrm{PhD}$ thesis, Middle East Technical University, Institute of Marine Sciences, Erdemli, Turkey, 2013.

Yücel, N.: Seasonal and spatial variation of bacterial production and abundance in the northern Levantine Sea, Mediterr. Mar. Sci., 18, 97-106, 2017.

Zamora, L. M., Prospero, J. M., and Hansell, D. A.: Organic nitrogen in aerosols and precipitation at Barbados and Miami: Implications regarding sources, transport and deposition to the western subtropical North Atlantic, J. Geophys. Res., 116, D20309, https://doi.org/10.1029/2011JD015660, 2011.

Zhang, Y., Zheng, L., Liu, X., Jickells, T., Cape, N., Goulding, K., Fangmeier, A., and Zhang, F.: Evidence for organic N deposition and its anthropogenic sources in China, Atmos. Environ., 42, 1035-1041, 2008. 